\title{
Proces Tadeusza Maja. Z dziejów oddziału AL „Świt” na Kielecczyźnie
}

W książce o starachowickim obozie pracy Christopher Browning pisze, że o ile Żydom ukrywającym się w lasach podczas drugiej wojny światowej groziło niebezpieczeństwo ze strony oddziałów takich jak AK i NSZ, o tyle grupy lewicowe, takie jak GL i AL, z zasady odnosiły się do nich przyjaźnie ${ }^{1}$. Niezależnie od tego, iloma przykładami można zilustrować tę tezę , przeczą jej procesy dowódców oskarżonych o mordy na Żydach: na Lubelszczyźnie Grzegorza Korczyńskiego i jego podkomendnych ${ }^{3}$, na Kielecczyźnie zaś, właśnie w okolicy Starachowic, Tadeusza Maja i jego oddziału „Świt”" W niniejszym tekście omawiam utrzymywane w ścisłej tajemnicy dzieje drugiego z nich, wpisane w pejzaż walk frakcyjnych polskich komunistów późnej epoki stalinowskiej.

\footnotetext{
${ }^{1}$ Christopher R. Browning, Remembering Survival. Inside a Nazi Slave-Labor Camp, New York-London: W.W. Norton \& Co., 2010, s. 252: „While a few partisan groups in the forest - usually those associated with the AL (Armia Ludowa, the Communist-oriented underground) - would accept Jews, those associated with the AK (the conservative nationalist underground Home Army) usually rejected them. More dangerously, some AK units and especially extremist units associated with the notorious National Armed Forces (NSZ) would either rob Jews, or simply kill them outright".

${ }^{2}$ Zob. relacje żydowskich partyzantów, głównie z zespołu $301 \mathrm{w}$ Archiwum Żydowskiego Instytutu Historycznego, zebrane w opracowaniu pt. Żydzi w walce 1939-1945. Opór i walka z faszyzmem w latach 1939-1945, wybór i red. Jerzy Diatłowicki, t. 1-2, Warszawa: Stowarzyszenie Żydów Kombatantów i Poszkodowanych w II Wojnie Światoweji i ŻIH, 2009-2010.

${ }^{3}$ Piotr Gontarczyk, Z genealogii elit PZPR. Przypadek Stefana Kiljanowicza vel Grzegorza Korczyńskiego, „Glaukopis” 2003, nr 1, s. 214-229. Materiały śledztwa i procesu Korczyńskiego: Archiwum Instytutu Pamięci Narodowej (dalej AIPN), 507/221. Piotr Gontarczyk był też pierwszym autorem, który odnalazł i opublikował materiały dotyczące procesu Tadeusza Maja, zob. na przykład Piotr Gontarczyk, Polska Partia Robotnicza. Droga do władzy 19411944, Warszawa: Fronda, 2003, s. 346-348; zob. też przypis 13.

${ }^{4}$ Materiały tego procesu znajdują się w Archiwum Akt Nowych w Warszawie (dalej AAN), Akta Prokuratury Generalnej (dalej PG), 21/99; ibidem, 8185, Akta osobowe Tadeusza Maja. Inne źródła z nim związane w różnych zespołach tematycznych: AIPN, na przykład materiały dotyczące Adama Bakalarczyka (sygn. 0703/1132). Uzupełniające materiały dotyczące procesu Jana Kozieła: Archiwum Państwowe m.st.Warszawy (dalej APW), Sąd Wojewódzki dla m.st.Warszawy (dalej SW), IV 3K.126/53, b.p.
} 
Morderstw, o które oskarżono Maja i jego ludzi, dokonano w lasach koło Iłży w okresie od przełomu czerwca i lipca 1944 do grudnia tego roku. Ich ofiarami padli żydowscy uciekinierzy z obozu pracy w Starachowicach, którym w obliczu wywózki do Birkenau pod koniec czerwca 1944 r. udało się przedrzeć do lasu . Jak wynika ze wspomnień tych, którzy przeżyli ${ }^{6}$, spotykali w nim partyzantów wszystkich działających w tym rejonie ugrupowań: AK , NSZ i AL. Ocaleni mówili o rabunkach, jakich doświadczyli ze strony tych formacji, i zabójstwach przez nie dokonanych, podkreślali zarazem, że tylko oddziały lewicowe gotowe były przyjmować Żydów w swoje szeregi i tylko one karały niekiedy swoich członków za - rzekomo wyłącznie samowolne - rabowanie i zabijanie Żydów ${ }^{8}$. Prezentowane w artykule materiały z procesów Tadeusza Maja i jego żołnierza Jana Kozieła zaprzeczają temu, że były to działania samowolne, o których nie wiedziało dowództwo. Poświadczają częste występowanie antysemityzmu wśród żołnierzy AL i pokazują, jak wcześnie problem postaw antyżydowskich, zazwyczaj wiązany dopiero z odwetem za stalinizm, podzielił polskich komunistów. Jednym z bohaterów narracji, która wyłania się z przytaczanych świadectw, jest Mieczysław Moczar, którego polityczne wpływy w roku 1968 przyczyniły się do ostatniej wielkiej emigracji żydowskiej z Polski.

\section{Część I. Polityczny kontekst procesu}

Tadeusz Maj, jeden z najważniejszych dowódcow partyzantki AL w Polsce w czasie drugiej wojny światowej, był do listopada 1943 r. dowódcą plutonu ZWZ w Rzeczniowie w powiecie starachowickim o pseudonimie „Róża”. Zmienił pseudonim w roku 1944, gdy został dowódcą oddziału AL „Świt” - na „Rózga” oraz „Łokietek”. Po wojnie, po krótkim okresie pracy w PPR w Radomiu, mianowano go najpierw

${ }^{5}$ Browning, Remembering Survival..., rozdział „Escapees”, s. 246-255.

${ }^{6} \mathrm{~W}$ rozdziale „Escapees” Browning przytacza ich świadectwa zgromadzone w Visual History Archive, USC Shoah Foundation Institute for Visual History and Education, University of Southern California (VHA); zob. także http://www.jewishgen.org/yizkor/Wierzbnik/ Wierzbnik.html\#TOC332, dostęp 6 IX 2011 r., s. 331-333, 362 i n. Jedno z nich (Browning, Remembering Survival..., s. 250-251), złożone przez Louisa Lejba Feintucha w roku 1998, dotyczące morderstwa dokonanego przez niezidentyfikowaną formację partyzacką, z pewnością odnosi się do oddziału AL „Świt” pod dowództwem Tadeusza Maja, zob. dalej w sekcji „Kotyska”.

${ }^{7}$ Historię zabójstwa grupy Żydów przez oddział AK pod dowództwem Wincentego Tomasika „Potoka” opisuje Alina Skibińska w artykule „Dostał 10 lat, ale za co?”. Analiza motywacji sprawców zbrodni na Żydach na wsi kieleckiej w latach 1942-1944 [w:] Zarys krajobrazu. Wieś polska wobec zagłady Żydów 1942-1945, red. Barbara Engelking, Jan Grabowski, Warszawa: Stowarzyszenie Centrum Badań nad Zagładą Żydów, 2011, s. 401-405, 436.

${ }^{8}$ Browning, Remembering Survival..., s. 250-254; tu opowieść o wyroku wydanym przez Mieczysława Moczara na zabójców żydowskiego żołnierza; to samo w relacji Dawida Saliego, In the Woods of Wierzbnik (with the Partisans), Księga pamięci Wierzbnika, s. 333, http://www.jewishgen.org/yizkor/Wierzbnik/wie332.html, dostęp 6 IX 2011 r. Być może tej właśnie sprawy dotyczy zabójstwo omawiane w sekcji „Sprawa «Ząbka»”. 
zastępcą dowódcy brygady Korpusu Bezpieczeństwa Wewnętrznego w Lublinie, następnie od lipca 1945 r. został wiceprzewodniczącym Wojewódzkiej Rady Narodowej w Kielcach, w latach 1946-1949 zaś pełnił funkcję przewodniczącego Komisji Specjalnej do Walki z Nadużyciami i Szkodnictwem Gospodarczym w tym mieście; prowadzono w niej dochodzenia przeciwko tzw. spekulantom. Od roku 1950 do momentu aresztowania w maju $1951 \mathrm{r}$. Tadeusz Maj, który skądinąd nigdy nie studiował prawa, pracował na stanowisku prokuratorskim w Łodzi.

W jego teczce w Archiwum Akt Nowych znajduje się opatrzony nagłówkiem „ściśle tajne” list adresowany do KC PPR, prawdopodobnie do Zenona Kliszki 15 maja 1945 r. wysłali go dwaj pracownicy KBW, kpt. Niewiadomski, szef Oddziału Personalnego, i mjr Tadeusz Orkan-Łęcki ${ }^{10}$, szef Zarządu Polityczno-Wychowawczego. W liście czytamy między innymi:

Odsyłamy do Waszej dyspozycji skierowanego do nas mjr. MAJA TADEUSZA, który na powierzonym mu stanowisku dowódcy dla spraw polityczno-wychowawczych III Brygady KBW nie wywiązał się ze swych zadań. [...] Na wielu odcinkach [Maj] okazał się nacjonalistą, manifestując swoją niechęć do ludzi innej narodowości (żydzi). W[edłu]g danych od byłych partyzantów tkwiących w oddziałach AL, mjr Maj dopuszczał się rozstrzeliwania żydów zbiegłych z niemieckich obozów ${ }^{11}$.

Mimo pogłosek krążących od zakończenia wojny ${ }^{12}$ śledztwa dotyczącego mordowania Żydów przez partyzantów Armii Ludowej ${ }^{13}$ nie rozpoczęto aż do jesieni

${ }^{9} \mathrm{Z}$ zeznania znajdującego się w teczce Tadeusza Orkana-Łęckiego jako tajnego współpracownika UB ps. „Pióro” (AIPN, 00945/170) wynika, że w sprawie Maja złożył on „pisemny meldunek do KC PPR na ręce towarzysza Kliszki” (ibidem, k. 43).

${ }^{10}$ Od lata 1944 r. Tadeusz Orkan-Łęcki był zastępcą Tadeusza Maja, dowódcy II Brygady AL „Świt”. W trakcie procesu za zabójstwa Żydów, prowadzonego równolegle z procesem Maja (APW, SW, IV3K.126/53, k. 61), Jan Kozieł „Galant”, członek oddziału AL „Świt”, oskarżył Tadeusza Łęckiego „Orkana” o antysemityzm i zlecanie zabójstw Żydów.

${ }^{11}$ AAN, 8185, Akta osobowe Tadeusza Maja, k. 7. Zachowałam pisownię oryginału. W notatce służbowej z 28 III 1951 r. oficer Ludwik Sikora pisze, że Adam Bakalarczyk „Dulka” mówił Wacławowi Traczowi „Skórze”, że „Łokietek [Tadeusz Maj] był wzywany do Komitetu Centralnego przez tow. Zambrowskiego" (ibidem).

${ }^{12}$ Zob. wypowiedź Romana Przybyłowskiego, zastępcy komendanta WUBP w Kielcach, w śledztwie IPN w sprawie pogromu kieleckiego 1946 r.: „Wojewodą kieleckim był Eugeniusz Wiślicz-Iwańczyk. Z opowiadań wiem, że był on antysemitą [...]. Również z opowiadania wiem, że z jego rozkazu strzelano do Żydów, którzy usiłowali dołączyć do jego oddziałów”, cyt. za: Protokót przestuchania zastępcy komendanta wojewódzkiego MO w Kielcach Romana Przybyłowskiego [w:] Wokót pogromu kieleckiego, red. Łukasz Kamiński, Jan Żaryn, t. 1, Kielce: IPN, 2006, s. 378.

${ }^{13}$ Niektóre dokumenty z tych dochodzeń zostały opublikowane w: Tajne oblicze GL-AL i PPR. Dokumenty, oprac. Marek J. Chodakiewicz, Piotr Gontarczyk, Leszek Żebrowski, t. 1-3, Warszawa: Burchard Edition, 1997-1999. Niektórzy historycy, na przykład Ryszard Nazarewicz, próbowali podważyć wiarygodność materiałów obciążających żołnierzy AL i GL, sugerując, że zostały sfabrykowane na zamówienie polityczne. Oprócz zeznań żołnierzy oddziału 
1948 r., gdy powstało zapotrzebowanie na materiały obciążające Władysława Gomułkę i jego współpracowników, w tym Mieczysława Moczara i Grzegorza Korczyńskiego. Zwalczaniem napiętnowanej na plenum KC PPR „gomułkowszczyzny” i „odchylenia prawicowo-nacjonalistycznego” zajęła się wówczas grupa specjalna, działająca pod kierunkiem wiceministra bezpieczeństwa publicznego Romana Romkowskiego. 3 marca 1950 r. przekształciła się ona w Biuro Specjalne MBP, a od 30 listopada 1951 r. w X Departament tego ministerstwa. Na jego czele stanął Anatol Fejgin, natomiast wicedyrektorami zostali Józef Światło i Henryk Piasecki. Dochodzenia w sprawach, które określano jako „linia 3” - były wśród nich „prowokacje i dywersja powstała w czasie okupacji w PPR i AL” - nadzorował pierwszy z wymienionych, wcześniej piastujący stanowisko zastępcy Fejgina w grupie specjalnej i w Biurze Specjalnym ${ }^{14}$.

Tadeuszem Orkanem-Łęckim, jednym ze współautorów meldunku przytoczonego na początku, Zarząd Informacji KBW zainteresował się jednak, jeszcze zanim walki frakcyjne w PPR pozbawiły Gomułkę stanowiska I sekretarza PPR ${ }^{15}$. Dowiadujemy się tego ze znajdującego się w teczce „Orkana” oświadczenia z 29 lutego 1948 r., dotyczącego jego zwierzchnika Eugeniusza Wiślicza-Iwańczyka ${ }^{16}$, jednej z najważniejszych po Moczarze osób w kieleckim środowisku władzy. Iwańczyk był założycielem oddziału „Świt”, którego dowódcą mianował Tadeusza Maja, Tadeusza Łęckiego zaś jego zastępcą. W oświadczeniu Orkan-Łęcki napisał, że „Wiślicz” nie tylko należał wcześniej do AK, co w tamtej epoce miało charakter niebezpiecznego donosu, lecz także żył w „wielkiej przyjaźni z gestapowcem, nadleśniczym Krügerem z Marcul, zastrzelonym następnie przez akowskie podziemie"17. Dał też do zrozumienia, że „Wiślicz” był zamieszany w sprawę zamordowania w Jasieńcu

\footnotetext{
„Świt” w procesie Maja przeczą temu inne dokumenty: meldunek z roku 1945, od którego rozpoczęłam niniejszy tekst, przesłuchanie Józefa Bugajskiego z roku 1948, zweryfikowany przez Władysława Sobczyńskiego (zob. dalej), wypowiedź Romana Przybyłowskiego cytowana w przypisie 32 i zawartość teczki TW ps. „Pióro” - Tadeusza Orkana-Łęckiego.

${ }^{14}$ Chronologia na podstawie: Andrzej Paczkowski, Trzy twarze Józefa Światty. Przyczynek do historii komunizmu w Polsce, Warszawa: Prószyński i S-ka, 2009, s. 112, 130, 148 i n.

${ }^{15}$ Na posiedzeniu KC PPR, które odbywało się w dniach 31 VIII 1948-3 IX 1948, zastapił go Bolesław Bierut.

${ }^{16}$ Eugeniusz Iwańczyk, „Wiślicz”, „Stary Jakub”, przed wojną w Strzelcu, BBWR, OZN, w czasie wojny w ZWZ, dowódca plutonu AK Podobwodu „Wola”, organizator „Świtu”, oddziału AL na Kielecczyźnie. Od maja 1944 r. szef sztabu Obwodu III Radomsko-Kieleckiego Armii Ludowej. Gdy w końcu czerwca 1944 r. dowództwo obwodu AL objął Mieczysław Moczar „Mietek”, Wiślicz-Iwańczyk został jego zastępcą (za: Mieczysław Wieczorek, Armia Ludowa. Działalność bojowa 1944-1945, Warszawa: Wydawnictwo MON, 1984, s. 94). Po wojnie objął stanowisko wojewody kieleckiego, które stracił w roku 1948 (zob. AAN, 8500, Akta osobowe Eugeniusza Wiślicza-Iwańczyka). Następnie był też posłem na Sejm PRL z klubu PZPR (ibidem, PG, 21/99, k. 19). Zob. Eugeniusz Wiślicz-Iwańczyk, Echa Puszczy Jodłowej, Warszawa: Wydawnictwo MON, 1969.
}

${ }^{17}$ Zob. przypis 39. 
niewymienionego z nazwiska komunisty ${ }^{18}$. Z dużym prawdopodobieństwem można przypuszczać, że właśnie od tego zeznania rozpoczęło się dochodzenie pod kryptonimem „Jesion” (być może od wspomnianego Jasieńca Iłżeckiego), przejęte następnie przez Departament X MBP.

Drugim w kolejności dokumentem świadczącym o wczesnym zainteresowaniu wywiadu wojskowego „Orkanem” był opatrzony datą 30 sierpnia 1948 r. raport starszego oficera IV Oddziału Informacji KBW, kpt. Lewickiego. Informował on swojego szefa, płk. Antoniego Pundę, że zgodnie z jego poleceniem przeprowadził poufny wywiad na temat „Orkana”, sprowokowany - jak się dowiadujemy - „meldunkiem posiadanym przez ppor. Osińskiego, oficera Wydziału Personalnego VII Pułku KBW w Kielcach”19. Z wywiadu wynikało, że Orkan-Łęcki, należący wówczas podobnie jak Wiślicz-Iwańczyk do ZWZ20, w roku 1940 został aresztowany przez Niemców. W śledztwie miał wydać im „całą organizację podziemną ZWZ, w wyniku czego kilkudziesięciu ludzi zostało przez Gestapo aresztowanych” i wysłanych do Auschwitz. Był wśród nich także rozmówca Lewickiego, Stanisław Kosowski, po wojnie sekretarz gminy Mirzec. Wprawdzie „Orkan” też znalazł się w Auschwitz, ale „został zastępcą blokowego, rozdawał więźniom żywność [...] chodził elegancko ubrany i nie dbał o terror panujący w obozie"21. Po roku opuścił obóz, w czym dopatrywano się dowodu na jego współpracę z Niemcami.

Gdy w związku z odsunięciem Gomułki od władzy partyzantów „Świtu” - uważanych pośrednio, ze względu na ich kontakty z Moczarem, za jego stronników ${ }^{22}$ - zaczęto systematycznie przesłuchiwać, wywiad wewnętrzny wpadł na kolejne, jeszcze poważniejsze tropy. Kluczowym świadkiem w sygnalizowanej w oświadczeniu Orkana-Łęckiego „sprawie Tadeusza Maja” okazał się jego podkomendny Adam Bakalarczyk „Dulka”23. Wprawdzie zeznania składał dopiero w roku 1951,

${ }^{18}$ AIPN, 00945/170, Sprawozdanie kpt. Lewickiego dotyczące wywiadu przeprowadzonego w sprawie ppłk. Orkana-Łęckiego ze Sztabu KBW do szefa Zarządu Informacji KBW płk. Pundy, 30 VIII 1948 r., k. 20. Ściśle rzecz biorąc, chodzi o dwóch PPR-owców, por. przypis 39.

${ }^{19}$ Ibidem. Meldunek ppor. Osińskiego to prawdopodobnie odpis niesygnowanej notatki z 9 VIII 1948 r. (AIPN, 00945/170, k. 19).

${ }^{20}$ W zdekompletowanym Wyciągu ze sprawy „Jesion” z 12 II 1952 r. nigdzie indziej niepotwierdzona wzmianka, że Jerzy Pyzialski, szef wywiadu NOW, który zginął w Oświęcimiu, utrzymywał, iż Łęcki należał do NSZ (ibidem, k. 45).

${ }^{21}$ Ibidem, k. 21.

${ }^{22}$ Zob. Paczkowski, Trzy twarze Józefa Światty..., s. 112.

${ }^{23}$ Adam Bakalarczyk (ur. 1921), sekcyjny drużyny ZWZ w Rzeczniowie, następnie zastępca dowódcy oddziału AL „Świt” i szef ds. bezpieczeństwa II Brygady AL (zob. raporty o rabunkach, jakich dopuścił się, gdy pracował na tym stanowisku w roku 1946: AIPN, 703/1132, k. 7-74), następnie wykładowca i kierownik Katedry Centrum Wyszkolenia MBP w Legionowie, odwołany w czerwcu 1954 r.; 16 X 1956 r. jego zażalenie nadesłane do Komitetu ds. Bezpieczeństwa Publicznego rozpatrywał kolega z partyzantki, Marian Janic (AIPN, 703/1132, k. 205). Do życia publicznego wrócił po powrocie Mieczysława Moczara do władzy. Własną wersję wydarzeń spisał w utrzymanej w duchu „moczarowskim” książce wspomnieniowej, 
niemniej to w jego teczce w archiwum IPN znajdujemy o dwa lata wcześniejszy, z 22 września 1949 r., ślad dochodzenia. Jest to protokół przesłuchania Józefa Bugajskiego „Azji” ${ }^{24}$, w czasie wojny członka oddziału „Świt”, który wyliczył następujące zbrodnie oddziału:

1) obrabowanie i rozstrzelanie grupy 12 Żydów nad rzeką Kotyską (uczestnicy: Maj, Wacław Tracz, Bakalarczyk, Józef Kozieł i inni),

2) zabójstwo 4 Żydów w leśniczówce Lipie (uczestnicy jak wyżej plus Tadeusz Orkan-Łęcki),

3) zabójstwa Żydów dokonane przez adiutanta „Wiślicza” Edwarda Konopskiego „Ząbka”25, „za cichą zgodą Łokietka i Wiślicza”,

4) wrogość Maja i Łęckiego wobec nieznanej z nazwisk pary lekarzy Żydów, dr. Adama i dr Irki, przydzielonych do oddziału „Świt”, skutkująca ich wygnaniem i śmiercią przy przedzieraniu się przez front w okolicy Baranowa w październiku 1944 r. Do ich śmierci w niejasny sposób miał się też przyczynić Tadeusz Orkan-Łęcki ${ }^{26}$.

W roku 1947 lub 1948, służąc w Zarządzie Informacji KBW, Bugajski zameldował o zdarzeniach zastępcy szefa Zarządu płk. Władysławowi Sobczyńskiemu27; jego nazwisko wielokrotnie powraca w materiałach śledztwa. Jesienią 1948 r. Bugajski, odbywający wówczas karę więzienia za odmowę wykonania rozkazu (okoliczności nieznane), miał zostać w tej sprawie przesłuchany przez oficera Biura ds. Funkcjonariuszy $\mathrm{MBP}^{28}$.

W tym momencie przywołać należy nazwisko Józefa Światły, który od 1 października 1948 r. pracował w Departamencie I MBP (kontrwywiad) i był naczelnikiem Wydziału V ${ }^{29}$, następnie zaś obok Henryka Piaseckiego pełnił funkcję wicedyrektora Biura Specjalnego, które prowadziło sprawę „Wiślicza”. W głośnej książce

zob. Adam Bakalarczyk, Leśne boje. Wspomnienia oficera II Brygady AL „Świt”, Warszawa: Wydawnictwo MON, 1962.

${ }^{24}$ AIPN, 703/1132, Protokół przesłuchania świadka Józefa Bugajskiego, Sokołów, 22 IX 1949 r., k. 126. Bugajski odsiadywał wówczas wyrok z art. 118 par. 2 kk WP w związku z art. 115 par. 1 kk WP. Kopie tego protokołu zostały też włączone do akt procesu Maja (AAN, PG, 21/99), znajdują się także w teczce TW ps. „Pióro”, Tadeusza Orkana- Łęckiego (AIPN, 00945/170, k. 17), zob. dalej.

${ }^{25}$ Zob. sekcja „Sprawa «Ząbka»”.

${ }^{26}$ Zob. sekcja „Jak oskarżony Maj sam rozumie swoje zachowanie”.

${ }^{27}$ Informacja potwierdzona przez Sobczyńskiego, nie zweryfikowano jednak, czy ten przekazał ją zwierzchnikom (AAN, PG, 21/99, Protokół przesłuchania świadka Władysława Sobczyńskiego, 18 IX 1953 r., k. 428-431).

${ }^{28}$ Jak dotąd w Archiwum IPN udało się odnaleźć tylko odpisy niektórych materiałów z dochodzeń prowadzonych przez centralę MBP, które zachowały się w teczkach osobowych Adama Bakalarczyka i TW ps. „Pióro” - Tadeusza Orkana-Łęckiego. W tej drugiej są to odpisy z zeznań Józefa Bugajskiego (22 IX 1949 r.), Jana Świtka (21 III 1951 r.), Henryka Połowniaka (21 V 1951 r.), Jana Kozieła (23 VI 1951 r.), a także samego Tadeusza Łęckiego (29 II 1948 i 22 III 1951 r.).

${ }^{29}$ Za: Paczkowski, Trzy twarze Józefa Swiatty..., s. 111. 
opublikowanej już po jego ucieczce na Zachód Światło oznajmił: „W 1949 zostałem wezwany do gen. Romkowskiego i polecono mi zebrać materiały dotyczące osoby Wiślicza i grupy z nim związanej. Zwerbowano agentów [jednym z nich był Orkan-Łęcki, TW „Pióro” - J.T.-B.] i zaczęto Wiślicza inwigilować”30. W teczce osobowej Adama Bakalarczyka trafiamy na podsumowanie prowadzonego pod jego nadzorem śledztwa w postaci niedatowanego raportu, zatytułowanego „Sprawa krypt[onim] «Jesion»"31. Zaszyfrowane dochodzenie (nazwiska wykropkowane, uzupełnione pismem odręcznym) dotyczyło zwierzchnika oddziału „Świt”, Eugeniusza Wiślicza-Iwańczyka.

W raporcie podkreślono, że ludzie „Wiślicza”, zwanego dalej „Jesionem”, „wywodzący się z ZWZ, AK, NSZ, po wyzwoleniu przeniknęli do organów BP, MO, WP oraz Partii”32. Opinia ta znajduje oparcie w faktach: niemal wszyscy „świtowcy" byli wcześniej w ZWZ. Pierwszym przykładem jest sam Tadeusz Maj, dowódca ZWZ w Rzeczniowie. Jego zastępca „Orkan”, podobnie jak wspomniany Bugajski, pracowali po wojnie w KBW. Drugi zastępca Maja, Bakalarczyk, pracował jako wiceszef PUBP w Radomiu, gdzie zatrudniony był również Edward Pastuszko „Ptak”, wcześniej w PUBP w Ostrowcu. Kolejny „świtowiec”, Jan Kozieł, był komendantem posterunku MO w Skaryszewie ${ }^{33}$, a jeszcze inny, Jan Świtek, milicjantem w Częstochowie $^{34}$. Osobny rozdział stanowi kariera Władysława Sobczyńskiego ${ }^{35}$, szefa

${ }^{30}$ Zbigniew Błażyński, Mówi Józef Światło. Za kulisami bezpieki i partii 1940-1955, Warszawa: LTW, 2003, s. 130.

${ }^{31}$ AIPN, 703/1132, k. 144-156. Brak nazwiska osoby sporządzającej raport. Jest to fragment większej całości, brakuje 12 pierwszych stron tekstu.

${ }^{32}$ Zob. Roman Przybyłowski, : „w organach UB i MO na terenie Kielecczyzny w większości funkcje pełnili byli partyzanci oddziałów AL, głównie «Garbatego» (Stanisław Olczyk) i Wiślicza (Eugeniusz Wiślicz-Iwańczyk), jak również niektórych oddziałów BCh, m.in. Ozgi-Michalskiego" (Przestuchanie świadka Romana Przybytowskiego [w:] Wokót pogromu kieleckiego, t. 1, s. 377).

${ }^{33}$ APW, SW, IV3K.126/53, k. 43.

${ }^{34}$ APW, MBP, Akta sprawy nr 113/51 przeciwko Koziełowi Janowi, Odpis z odpisu, 21 III 1951 r. [?], b.p.

${ }^{35}$ Władysław Sobczyński, „Jurand”, „Kłych”, „Władek” (1904-1986), przed wojną członek KPP w Ostrowcu Świętokrzyskim, więziony w Berezie Kartuskiej, w latach 1939-1940 funkcjonariusz milicji sowieckiej w Hrubieszowie, potem w Rożyszczach, od czerwca $1941 \mathrm{r}$. współpracownik, potem funkcjonariusz NKWD, po wyszkoleniu wywiadowczym pod Smoleńskiem przerzucony w rejon Baranowicz, od lutego 1944 r. szef kontrwywiadu grupy Leona Kasmana „Janowskiego”. Od wiosny 1944 r. na Lubelszczyźnie (Lasy Parczewskie i Janowskie), skąd w ostatnich dniach maja przeszedł na Kielecczyznę. W ankiecie personalnej wśród organizacji, do których należał, oprócz PPR, WRN, BCh, AL wymienił też „ZWZ, AK i NSZ [!]” (zob. Ankieta personalna Władysława Sobczyńskiego [w:] Wokót pogromu kieleckiego, red. Łukasz Kamiński, Jan Żaryn, t. 2, Kielce: IPN, 2008, s. 412). W okresie od 27 VI 1945 do stycznia 1946 r. szef WUBP w Rzeszowie, następnie w Kielcach. Po pogromie kieleckim 1946 r. odwołany ze stanowiska, aresztowany, ukarany naganą przez CKKP za „brak czujności i bezradność”. W dniu 20 I 1952 r. zwolniony z pracy w organach bezpieczeństwa państwa na skutek zarzutu Biura Specjalnego o współuczestnictwo w mordowaniu 
WUBP w Rzeszowie i Kielcach w czasie pogromu w lipcu 1946 r., pracownika GRU, spadochroniarza, którego związki z „Wiśliczem” nie ulegały wątpliwości. Kariery polityczne na szczeblu centralnym zrobili także tacy ludzie z jego otoczenia, jak Mieczysław Róg-Świostek ${ }^{36}$ czy Marian Janic ${ }^{37}$. Niemal wszyscy wymienieni mają na swoim koncie wojenne mordy na Żydach.

Ponadto w raporcie ponad wszelką wątpliwość dowiedziono współpracy „Wiślicza” z gestapo ${ }^{38}$, która miała zaowocować zastrzeleniem w jego domu przez żandarmerię niemiecką „trzech gwardzistów” - członków PPR. „Wiśliczowi” nie popsuło to stosunków z gestapowcem i nadleśniczym Krügerem:

Sam „Jesion” przed CKKP przyznaje się do kontaktu z Krügerem, jak również do faktu likwidacji w jego domu trzech gwardzistów, z tym jednak, że [twierdzi, iż] kontakt z Krügerem utrzymywał na rozkaz swego dowódcy AK Lewońskiego Henryka w celach wywiadowczych.

Biuro Specjalne sprawdziło oczywiście tę informację.

Przesłuchany w charakterze świadka Lewoński Henryk [dowódca kompanii AK] zeznał, że nigdy nie dawał „Jesionowi” polecenia przeprowadzenia wywiadu. [...] Zapytany, dlaczego wystawił fikcyjne zaświadczenie [jakoby wydał mu takie polecenie], tłumaczył się tym, że „Jesion” prosił go o takie zaświadczenie, gdyż jest mu potrzebne do uzyskania Krzyża Walecznych. [...] Lewoński zrobił to dlatego, że chciał [dzięki wstawiennictwu WiśliczaIwańczyka, wówczas wojewody kieleckiego] uzyskać pracę ${ }^{39}$.

Żydów podczas walk partyzanckich w AL (AIPN, 0305/388, ibidem, 0193/7009, t. 1-2 (7591/ V); zob. Wiślicz-Iwańczyk o Sobczyńskim, Echa Puszczy Jodłowej, s. 186-189).

${ }^{36}$ Mieczysław Róg-Świostek opisuje je w książce pt. Czas przeszły i teraźniejszy, Warszawa: Książka i Wiedza, 1982. W roku wydania książki Świostek, od 1949 r. redaktor naczelny pisma „Chłopska Droga”, był podpułkownikiem rezerwy i członkiem Prezydium Zarządu Głównego ZBoWiD (ibidem, s. 116, 227).

${ }^{37}$ W roku 1956 Marian Janic został naczelnikiem Biura Skarg i Zażaleń Komitetu do spraw Bezpieczeństwa Publicznego. Oglądał wtedy akta procesu Tadeusza Maja, zob. AIPN, 703/1132, k. 205.

${ }^{38}$ Autor raportu powołuje się tu na zeznanie Stanisława Daniszewskiego i innych. Wspomina, że w więzieniu WUBP w Kielcach znajdują się gajowi Stanisław Łabędzki i Wincenty Piotrowski, podejrzani o udział w zadenuncjowaniu trzech PPR-owców. Zob. też Błażyński, Mówi Józef Światło..., s. 130. Materiały śledztwa (AIPN, 703/1132, Sprawa kryptonim „Jesion”, k. 148) potwierdzają jego zeznania, w tym wymienione przezeń nazwiska więźniów.

${ }^{39}$ Oprócz Lewońskiego przesłuchano również Antoniego Hedę „Szarego”, dowódcę AK na terenie, na którym działał „Wiślicz”. W ZWZ „Szary” podlegał „Wiśliczowi”. Potwierdził on, że „Wiślicz” współpracował z gestapo (AIPN, 703/1132, k. 149). W książce Wspomnienia „Szarego” (Warszawa 1992: Interim) Antoni Heda cytuje kronikarza podobwodu AK Mariana Langera, syna leśniczego z Klepacz: „W pobliskiej wsi Jasieniec Krueger [gestapowiec] wraz z żandarmerią zastrzelił trzech delegatow PPR z Radomia [...]. Działo się to w obecności tamtejszego mieszkańca, Eugeniusza Iwańczyka «Wiślicza» (późniejszego powojennego wojewody kieleckiego), który był chroniony przez Kruegera jako jego człowiek, o czym donosili 
Inny istotny dla omawianej sprawy dokument, również konsultowany przez Józefa Światłę, to „Raport o zezwolenie na werbunek do sprawy «Jesion»”. Por. Ludwik Sikora zabiegał o zgodę wicedyrektora Biura Specjalnego MBP Henryka Piaseckiego na werbunek Orkana-Łęckiego, co miało ułatwić śledztwo przeciwko „Wiśliczowi”. Jest to tekst łudząco podobny do omówionego wcześniej raportu w sprawie o kryptonimie „Jesion”: nazwiska są wykropkowane, uzupełnione następnie tym samym co poprzednio charakterem pisma. W dokumencie tym, przypominającym raczej akt oskarżenia niż wniosek o nadanie statusu tajnego współpracownika, wspomina się liczne zbrodnie „Orkana”, poczynając od „wsypy” ZWZ w roku 1940 po „antysemityzm i morderstwa dokonywane na osobach narodowości żydowskiej”. Wymieniono tu między innymi znaną nam już sprawę śmierci dr. Adama i dr Irki, wydanie rozkazu rozstrzelania koło Marcul Żydówki, która prosiła o przyjęcie do oddziału ${ }^{40}$, a także - na podstawie zaginionego ${ }^{41}$ zeznania Tadeusza Maja - namawianie tego ostatniego przez „Orkana” do likwidacji ppłk. Michała Jaworskiego, minera przysłanego do oddziału w charakterze doradcy politycznego (jego zeznanie przywołuję na końcu tekstu ${ }^{42}$ ). „Raport o zezwolenie na werbunek” pochodzi z 28 września 1951 r. Niespełna miesiąc później, 20 października, Józef Światło napisał na nim w alarmującym tonie: „Płk Piasecki. Nie należy iść na werbunek. Po pierwsze, O[rkan] sam jest jednym z figurantów i ewentualne wyłączenie go potem byłoby niemożliwe; po drugie, i to jest bodaj najgłówniejsze [sic!], nie wejdzie on, w naturalny sposób, do Wiślicza, od którego oddalony jest o setki kilometrów, przyjazd zaś Orkana do miejsca pobytu Wiślicza po zdjęciu Łokietka od razu wzbudzi jego podejrzenia, kiedy zaczną rozmawiać na temat przeszłości”"33. Obok widnieje odpowiedź Henryka Piaseckiego z 9 stycznia 1952 r.: „Płk Światło. Orkan-Łęcki został zawerbowany 19.10.19514, po uzyskaniu ustnej zgody w[i]ceministra [Wacława] Lewikowskiego. Zastrzeżenie poczynione zostało na piśmie po fakcie dokonanym, o czym meldowałem w[i]cemin[istrowi] Lewikowskiemu”45. Kontra Piaseckiego, który podał tu oczywistą nieprawdę ${ }^{46}$, jest najlepszym dowodem napięcia między nim a Światłą ${ }^{47}$. Silnie zaważyło ono na dalszym toku śledztwa.

naoczni świadkowie” (s. 44). Por. też opis pogrzebu Kruegera, zabitego przez zamachowców z AK: „na cmentarzu odbył się uroczysty pogrzeb [...] wśród przemawiających znalazł się także «wielki Polak» Iwańczyk-Wiślicz, podkreślając, jaką stratę poniosła III Rzesza” (s. 45).

${ }^{40}$ Zastrzelił ją Józef Kozieł, zob. sekcja „Mężczyźni i kobiety”.

${ }^{41}$ AIPN, 00945/170, k. 13. Jest to wzmianka o jednym z protokołów, o których wyłączeniu ze sprawy Maja informuje kpt. Jan Grzęda, zob. przypis 56.

${ }^{42}$ Zob. sekcja „Jak oskarżony Maj sam rozumie swoje zachowanie”.

${ }^{43}$ AIPN, 00945/170, k. 11.

${ }^{44}$ Naprawdę werbunku dokonano 22 X 1951 r., zob. dalej.

${ }^{45}$ AIPN, 00945/170, k. 11.

${ }^{46}$ Prawdziwe zobowiązanie do współpracy, pisane ręką Tadeusza Orkana-Łęckiego, opatrzone jest datą 22 X 1951 r. (ibidem, k. 16).

${ }^{47}$ O rywalizacji Światło-Piasecki zob. Paczkowski, Trzy twarze Józefa Światty..., passim. 
Decyzja Piaseckiego, której z punktu widzenia śledztwa nie sposób obronićc ${ }^{48}$, umożliwiła roztoczenie nad „Orkanem” parasola ochronnego. Wydano ją, mimo że od 1 lipca gotowy był wniosek o aresztowanie „Orkana” (czekał na podpis któregoś z dwóch rywalizujących ze sobą wicedyrektorów Biura Specjalnego), w którym na sześciu stronach wymieniano stawiane mu zarzuty ${ }^{49}$, sformułowane na podstawie zeznań Jana Barszcza (16 marca 1951 r.), Jana Świtka (21 marca 1951 r.), Tadeusza Maja (2 czerwca 1951 r.), Jana Kozieła (21 czerwca 1951 r.) i Adama Bakalarczyka (28 czerwca 1951 r.). Innym ważnym dokumentem było oświadczenie z 18 maja 1951 r. dowódcy 153. Batalionu Wojsk Ochrony Pogranicza mjr. Henryka Połowniaka, w czasie wojny pod pseudonimem „Zygmunt” pełniącego funkcję dowódcy okręgu GL, który nie tylko potwierdził wszystkie zarzuty przeciwko „Orkanowi”50, lecz także dodał kilka nowych. O tym, że toczy się śledztwo dotyczące kieleckich partyzantów, w tym enkawudzisty Władysława Sobczyńskiego, wicedyrektor Biura Specjalnego Henryk Piasecki szczegółowo informował ministra Stanisława Radkiewicza w swoim piśmie z 4 lipca 1951 r. ${ }^{51}$

Warto wspomnieć o znaczącej różnicy sformułowań pomiędzy „Raportem o zezwolenie na werbunek” a wcześniejszym od niego o dwa miesiące „Wstępnym planem rozpracowania w sprawie Łęckiego Tadeusza ps. Orkan”52. O ile w tym ostatnim lipcowym dokumencie mówi się, powołując na słowa mjr. Połowniaka, że omawiane morderstwa „nie były zatwierdzone przez sztab AL, a były tylko jego [„Orkana”] samowolą, gdyż prawdopodobnie osoby te miały wiedzieć [sic!] wiele jego ciemnych sprawek”53, o tyle z październikowego „Raportu o werbunek” dowiadujemy się, że Orkan „od lipca 1944 zajmował kierownicze stanowisko w organizacji «Świt», a więc znał kierunek polityczny i działalność kierownictwa tej organizacji, i dopuszczając się ww. przestępstw, zrobił to w porozumieniu z dowództwem, ewentualnie wiedział, że czyny te pokrywają się z kierunkiem działalności «Świtu»" 54 . Jak to zaostrzenie tonu pogodzić z nietykalnością zaoferowaną „Orkanowi”? Wydaje się, że chodziło o to, by odpowiedzialnością za wszystko obarczyć przede wszystkim dowódcę oddziału Tadeusza Maja, który był wykonawcą wyroków zapadających gdzie indziej. Świadczy o tym zachowanie Maja w śledztwie, a także losy samego „Orkana”, o których opowiem dalej.

${ }^{48}$ O słuszności zastrzeżeń Światły, wskazującego na odległość dzielącą „Orkana” i „Wiślicza”, świadczą dalsze losy współpracy, której kres położyła ucieczka Światły, „ponieważ figurant do rozpracowania zamieszkuje w Lublinie i inf[ormator] Pióro nie ma możliwości kontaktowania się z nim” (AIPN, 00945/170, Ludwik Sikora, Notatka służbowa dotycząca informatora „Pióro”, 16 II 1954 r., k. 49).

${ }^{49}$ AIPN, 00945/170, k. 33-39.

${ }^{50}$ Ibidem, k. 26-27.

${ }^{51}$ AIPN, 703/1132, Meldunek dotyczący Władysława Sobczyńskiego, 4 VII 1951 r., Pismo Henryka Piaseckiego do ministra BP Stanisława Radkiewicza, k. 166-169.

${ }^{52}$ AIPN, 00945/170, k. 39.

${ }^{53}$ Ibidem, k. 39.

${ }^{54}$ Ibidem, k. 13. 
Niestety, w aktach śledztwa Maja z lat 1951-1953 występują poważne luki. W roku 1951 był on ponad 20 razy przesłuchiwany, czasem dwa, a nawet trzy razy dziennie. Potem jednak - gdyby oceniać to na podstawie zawartości akt - nastapił impas w śledztwie. Władze nie reagowały na wielokrotne monity ze strony rodziny, która nie wiedziała, gdzie przetrzymywany jest Maj. Z akt procesu wynika, że w roku 1952 nie odbyło się ani jedno przesłuchanie ${ }^{55}$. Kolejne (Barszcz, Świtek, Tracz - zob. dalej) nastąpiły dopiero w marcu $1953 \mathrm{r}$.

Zdumiewającym wydarzeniem w maju tego roku było wydanie postanowienia o wyłączeniu ze sprawy aż siedemnastu protokołów przesłuchań i trzech zeznań własnych Maja, ponieważ „nie pozostają w związku z zarzucanym czynem podejrzanemu [tak w oryginale - J.T.-B.]”56. W teczce Bakalarczyka udało się odnaleźć jeden $z$ tych dokumentów ${ }^{57}$ (w teczce „Orkana” zaś wzmiankę o kolejnym ${ }^{58}$ ). Ponieważ 4 czerwca Maja przesłuchiwano aż t r z y k r o t n i e, może zawierać on sugestię o kierunku dochodzenia. Rzeczywiście, w sensie ścisłym zeznanie Maja istotnie nie dotyczy zbrodni z lata 1944 r., niemniej pozostaje z nimi w pewnym związku. Odnosi się bowiem do pogromu kieleckiego ${ }^{59}$. Co ciekawe, w dniu pogromu w Kielcach przebywali zarówno Maj, jak i Bakalarczyk ${ }^{60}$, nie mówiąc rzecz jasna o Sobczyńskim, szefie kieleckiego WUBP, czy Wiśliczu-Iwańczyku, ówczesnym wojewodzie kieleckim. Wątek kielecki w śledztwie Maja mógł mieć zatem związek z prowadzoną przez Biuro Specjalne „sprawą Sobczyńskiego i Wiślicza”61.

${ }^{55} \mathrm{Z}$ zachowanej we fragmentach charakterystyki wynika, że oprócz Wiślicza-Iwańczyka figurantem rozpracowywanym przez Departament X był też Mieczysław Róg-Świostek, zob. AIPN, 00945/170, Charakterystyka agentury w sprawie „Jesion”, 12 I 1952 r., k. 46

${ }^{56}$ Postanowienia o wyłączeniu protokołów: dwóch z $30 \mathrm{~V}$, dwóch z $31 \mathrm{~V}$, po jednym z 1, 2 i 3 VI, trzech z 4 VI (jeden z protokołów z tego dnia odnalazłam w teczce Adama Bakalarczyka, por. przypis 57), po jednym z 5, 6 i 8 VI oraz jeden z 6 VII 1951 r., a także zeznań własnych z 11, 12 i 13 VI 1951 r., podpisane przez kpt. Jana Grzędę, 18 V 1953 r. (AAN, PG, 21/99, k. 369).

${ }^{57}$ Chodzi o Protokół przesłuchania podejrzanego Tadeusza Maja z 4 VI 1951 r. (AIPN, 703/1132, k. 95 i n.).

${ }^{58}$ Wzmianka o przesłuchaniu z 2 VI 1951 r., dotyczącym Orkana-Łęckiego, który próbował namówić Maja do likwidacji minera Michała Jaworskiego, znajduje się w omawianym Raporcie o zgodę na werbunek (AIPN, 00045/170, k. 13).

${ }^{59}$ Maj opisuje wypadki uliczne, których był świadkiem, odnotowuje także zdumiewającą bierność Sobczyńskiego, wówczas szefa WUBP w Kielcach (AIPN, 703/1132, Protokół przesłuchania podejrzanego Tadeusza Maja, 4 VI 1951 r., k. 95-75).

${ }^{60}$ Do czerwca 1946 r. pracował w Radomiu. „Następnie zostałem służbowo przeniesiony do WUBP Kielce, skąd po upływie miesiąca wysłano mnie na Centralną Szkołę MBP do Łodzi” (ibidem, Protokół przesłuchania podejrzanego Antoniego [sic!] Bakalarczyka, 29 VI 1949 r., k. 55).

${ }^{61} 25$ VI 1954 r. Franciszek Maj napisał list do Rady Państwa, w którym przypomniał: „Nie kto inny jak on [Tadeusz Maj] brał czynny udział w rozładowywaniu sytuacji w czasie pogromu kieleckiego. Zorganizował transport rannych Żydów, za co dostał pochwałę, która jest w aktach sprawy. Trzeba nadmienić, że Łokietek, oskarżając Sobczyńskiego i Wiślicza, 
W aktach procesu Maja znajdują się tylko pojedyncze protokoły przesłuchań Sobczyńskiego i Wiślicza-Iwańczyka z jesieni 1953 r., ale pierwszy z wymienionych wspomniał też o jakimś przesłuchaniu sprzed 2 lat. Obaj mówili niewiele, wypierali się własnej odpowiedzialności za zbrodnię nad rzeką Kotyską. „Wiślicz” zaprzeczał, że wydał Majowi rozkaz rozstrzelania Żydów ${ }^{62}$, twierdził, iż w oddziale bywał zawsze w towarzystwie Sobczyńskiego i podkreślał jego autorytet jako oficera NKWD. Utrzymywał, że właśnie od niego miał się też dowiedzieć o rozstrzelaniu Żydów przez Maja. Dodał, że Maj podlegał bezpośrednio „komendantowi okręgu Saszko i jego zastępcy Zygmuntowi [Henrykowi] Połowniakowi”, „pośrednio zaś [...] podlegał organizacyjnie dowództwu obwodu, w tej liczbie i mnie”. Określenie „w tej liczbie” jest wskazaniem na dowódcę III Obwodu AL Mieczysława Moczara, od roku 1948 znajdującego się w niełasce ${ }^{63}$.

Z kolei Władysław Sobczyński, szef bezpieczeństwa III Obwodu AL, który również napomknął o szefie obwodu Moczarze, podkreślał, że „zasadniczo Maj winien był wykonywać tylko zlecenia Wiślicza”64, był jednak niesubordynowany i czasem odmawiał wykonania rozkazów. „Między mną a Majem żadnego stosunku służbowego nie było" - zaznaczył. Potwierdził, że w oddziale bywał tylko w towarzystwie „Wiślicza”. O tym, że „Maj rozstrzelał 13 żydów”, dowiedział się dopiero z meldunku, który złożył mu Józef Bugajski w roku 1947 lub 194865.

Sprawą „odpryskową”, którą Departament X finalizował jesienią 1953 r., było dochodzenie przeciwko żołnierzowi oddziału „Świt” Janowi Koziełowi, aresztowanemu pod zarzutem mordów na Żydach wkrótce po zatrzymaniu Maja. 12 października sformułowano akt oskarżenia, który zatwierdził bezpośredni przełożony Światły Anatol Fejgin ${ }^{66}$. W trakcie przesłuchań Kozieł mówił: „Do oddziału Łokietka często przyjeżdżali Moczar, Zygmunt [Henryk Połowniak], Sobczyński oraz jeszcze ktoś (tęgiej budowy), nazwiska jego nie znam”67.

stwierdził, że źródeł pogromu kieleckiego należy dopatrywać się jeszcze w czasie okupacji” (AAN, PG, 21/99, k. 552).

${ }^{62}$ AAN, PG, 21/99, Protokół przesłuchania świadka Eugeniusza Wiślicza-Iwańczyka, 16 X 1953 r., k. 432-435.

${ }^{63} \mathrm{O}$ okolicznościach utraty wpływów przez Moczara w okresie zwalczania „odchylenia nacjonalistyczno-prawicowego” zob. Krzysztof Lesiakowski, Mieczysław Moczar „Mietek”. Biografia polityczna, Warszawa: Rytm, 1998.

${ }^{64}$ AAN, 21/99, Protokół przesłuchania świadka Władysława Sobczyńskiego, Warszawa, 18 IX 1953 r., k. 428-431.

${ }^{65}$ Zob. sekcja „«Wiślicz» i Sobczyński”.

${ }^{66}$ APW, SW, IV3K.126/53, Akt oskarżenia przeciwko Koziełowi Janowi, 12 X 1953 r., k. 4. Proces rozpocznie się 24 I 1954 r. Wyrok zapadnie 16 marca 1954, a więc na tydzień przed początkiem rozprawy Maja. Kozieł został skazany na 5 lat i 1 miesiąc więzienia i na utratę praw publicznych na 2 lata. 2 V 1956 r. reszta kary została Koziełowi darowana. Obu oskarżonych sądził ten sam sędzia Z. Kaczyński.

${ }^{67}$ APW, MBP, Protokół przesłuchania podejrzanego Jana Kozieła, 10 VI 1951 r., b.p. 
Po ucieczce Światły 5 grudnia 1953 r. ${ }^{68}$ śledztwo w sprawach związanych ze „świtowcami” gwałtownie straciło impet, tym bardziej że w konsekwencji ucieczki 1 stycznia 1954 r. został zdymisjonowany także Anatol Fejgin. Dopiero wówczas władze zdecydowały się odpowiedzieć na monity rodziny Maja, by wyjaśnić odwlekanie procesu. O zmianie atmosfery możemy też wnioskować na podstawie nagłego zainteresowania władz stanem zdrowia więźnia. W notatce z 4 stycznia $1954 \mathrm{r}$. prokurator Władysław Dymant informował (nie wiadomo kogo), że przygotowanie aktu oskarżenia Departament X opóźniał „w związku ze sprawą Sobczyńskiego i Wiślicza”69. Dziesięć dni później, 14 stycznia, protokoły przesłuchań Sobczyńskiego, Wiślicza-Iwańczyka i Maja przesłano naczelnemu prokuratorowi wojskowemu gen. Stanisławowi Zarako-Zarakowskiemu ${ }^{70}$. W akcie oskarżenia z 22 stycznia 1954 r., sporządzonym przez kpt. Mariana Szpiegę, nazwiska obu zwierzchników Maja w ogóle już się nie pojawiają ${ }^{71}$.

Na rozprawę Maja (27 marca 1954 r.) w charakterze świadka wezwano tylko „Wiślicza”72. Przeciwko przesłuchaniu Sobczyńskiego, o które wnioskował Maj, wystąpił sam prokurator, wnosząc o odczytanie jego zeznań złożonych w śledztwie $^{73}$. Obciążające ich obu zeznania (Bakalarczyka, Tracza, Barszcza, zob. dalej), a także sentencja wyroku, w którym wydanie przez nich rozkazu egzekucji uznano za powód do złagodzenia Majowi kary ${ }^{74}$, nie sprowokowały jednak prokuratora do pociągnięcia ich do odpowiedzialności. Najbardziej zagadkowym elementem procesu Maja były rozgrywki wokół Mieczysława Moczara. Jego nazwisko wypłynęło niespodziewanie 28 czerwca 1951 r. w zeznaniu Adama Bakalarczyka: „W czasie

${ }^{68}$ Zob. Paczkowski, Trzy twarze Józefa Światty..., s. 173-175.

${ }^{69}$ AAN, PG, 21/99, Notatka z 4 I 1954 r., k. 217.

${ }^{70} 16$ III 1954 r. przesyłkę uzupełniono protokołem zeznań Bakalarczyka z 16 II $1954 \mathrm{r}$. (ibidem, Pismo Kazimierza Kosztirki, dyrektora Departamentu MBP, 16 III 1954 r., k. 176). Andrzej Paczkowski określa poglądy generała mianem „antysemickich” (idem, Trzy twarze Józefa Światty..., s. 103).

${ }^{71}$ AAN, PG, 21/99, Akt oskarżenia przeciwko Tadeuszowi Majowi, sporządzony przez kpt. Mariana Szpiegę, 22 I 1953 r., k. 148-151.

72 Ibidem, Protokół rozprawy głównej przeciwko Tadeuszowi Majowi, 27 III 1954 r., k. 424. Na rozprawie Wiślicz-Iwańczyk mówił między innymi: „Sobczyński mówił mi, że Żydzi włóczą się po lesie i narażają oddziały na niebezpieczeństwo, z tego wynika, że odnosił się raczej pozytywnie do tego, co zrobił Łokietek”.

${ }^{73}$ Ibidem, k. 526-527: „oskarżony wnosi o przesłuchanie świadka Sobczyńskiego. Prokurator oponuje przeciwko wnioskowi oskarżonego i wnosi o odczytanie zeznań świadka Sobczyńskiego. Odnośnie [do] wniosku oskarżonego w sprawie wezwania Sobczyńskiego Władysława sąd postanowił nie uwzględnić, ponieważ co do okoliczności, na którą świadek ma zeznawać, sąd się ustosunkuje w trybie wyrokowania”.

${ }^{74}$ AAN, PG, 21/99, Sąd Wojewódzki dla m.st.Warszawy, Sentencja wyroku w sprawie przeciwko Tadeuszowi Majowi, 30 III 1954 r., k. 537-538: „biorąc pod uwagę logiczny wniosek, iż Sobczyński i Wiślicz w wypadku, gdyby faktycznie wydali [Majowi] to polecenie i tak nie przyznają się do tego [...] sąd nie wyjaśnił dostatecznie tego zagadnienia, tak istotnego dla sprawy [...] i dlatego zgodnie z zasadą in dubio pro reo wątpliwości te rozstrzygnął na korzyść oskarżonego, przyjmując, iż działał on z polecenia Sobczyńskiego i Wiślicza”. 
okupacji mówił mi Łokietek, że pieniądze i inne rzeczy zabrane Żydom oddał Moczarowi"75. W dokumentach po tej dacie wątek Moczara nie wracał przez ponad trzy lata, zapewne nie ze względu na przeoczenie ze strony śledczych ${ }^{76}$. Jeśli tę przesłankę połączymy z informacją o wyłączeniu z akt sprawy Maja 17 protokołów, uzyskamy podstawę do przypuszczeń, że obok „sprawy pogromu kieleckiego”, z którą łączyły się nazwiska Wiślicza-Iwańczyka i Sobczyńskiego, mógł się w nich pojawiać także wątek Moczara. Nazwisko to powróciło w materiałach procesu Maja dopiero 5 marca 1954 r. - w piśmie adwokatów Maja Aleksandra Soroki i Jana Załęckiego. Informowali oni: „pieniądze zabrane Żydom [Maj] oddał swemu przełożonemu, komendantowi Obwodu AL, Moczarowi”77. Dwa tygodnie później obrona zmieniła gwałtownie front, wnioskując „o dopuszczenie dowodu z zeznań świadka gen. Moczara, ob[ecnie] przewodniczącego Prezydium WRN w Lublinie ${ }^{78}$, na całokształt działalności partyzanckiej oskarżonego"79. W reakcji na to w tydzień później Maj cofnął adwokatom pełnomocnictwo i złożył oświadczenie, że będzie się bronił sam ${ }^{80}$.

Na tym jednak wątek Moczara wcale się nie zakończył. 29 marca 1954 r. autor aktu oskarżenia kpt. Marian Szpiega sporządził notatkę informacyjną dotyczącą zeznań Bakalarczyka i Wiślicza-Iwańczyka na rozprawie przeciwko Majowi. Zrelacjonował w niej zeznania Bakalarczyka, obciążające Sobczyńskiego i „Wiślicza”. Następnie podkreślił, iż na rozprawie Bakalarczyk „podał, że pieniądze zrabowane Żydom zostały przekazane Moczarowi”" . Do dwukrotnego zeznania Bakalarczyka władze przywiązywały tak dużą wagę, że aby nie ujrzało ono światła dziennego, uciekły się do fałszerstwa. Dowiadujemy się o nim dzięki notatce służbowej naczelnika Wydziału IV Biura ds. Funkcjonaruszy MBP z 10 maja 1954 r.:

ponieważ Bakalarczyk w czasie pierwszego przesłuchania podał pewien fakt niemający zasadniczego znaczenia dla sprawy Maja, a niewskazanym byłoby, by był on ujawniony na rozprawie sądowej, d o k o n a n o p o n o wnego spisania protokołu z Bakalarczykiem, pomijając ten fakt.

${ }^{75}$ AIPN, 703/1132, Protokół przesłuchania świadka Adama Bakalarczyka, 28 VI 1951 r., k. 101. Świadkowie (na przykład Barszcz) zeznawali, że to właśnie Bakalarczyk zbierał pieniądze i kosztowności odebrane Żydom nad Kotyską.

${ }^{76}$ Expressis verbis mówi się o tym w skierowanym do płk. Siedleckiego piśmie dotyczącym zeznania Bakalarczyka z maja 1953 r., podpisanym przez kpt. Kałkusa, kierownika Sekcji I Wydziału IV Biura ds. Funkcjonariuszy MBP: „przedmiotowej sprawy nie można rozpatrywać w oderwaniu od całości zagadnień, którymi zainteresowany jest Departament X MBP”.

${ }^{77}$ AAN, PG, 21/99, k. 444.

${ }^{78}$ W rzeczywistości Mieczysław Moczar w latach 1952-1954 pełnił funkcję przewodniczącego Wojewódzkiej Rady Narodowej w Białymstoku, zob. Krzysztof Lesiakowski, Mieczystaw Moczar „Mietek”. Biografia polityczna, Warszawa: Rytm, 1998, s. 157-171.

${ }^{79}$ AAN, PG, 21/99, k. 474.

${ }^{80}$ Ibidem, k. 476-478.

${ }^{81}$ AIPN, 703/1132, k. 158. Przypomnę, że po raz pierwszy Bakalarczyk poinformował o tym fakcie w czasie przesłuchania 28 VI $1951 \mathrm{r}$. 
Mimo to na rozprawie sądowej Bakalarczyk ten fakt poruszył. [...] Biorąc pod uwagę powyższe, wnoszę o zwolnienie Bakalarczyka Adama z pracy w aparacie b[ezpieczeństwa] p[ublicznego] [.... ${ }^{82}$.

Musimy jeszcze doprowadzić do końca historię TW „Pióro”, Tadeusza Orkana-Łęckiego, który mimo że podpisując zgodę na współpracę, przyznał się do zarzucanych mu czynów ${ }^{83}$, nigdy nie poniósł za nie kary. Nadanie mu statusu tajnego współpracownika nie było pierwszym „szczęśliwym trafem”, jaki mu się przydarzył. Wcześniejszy odnotowano 20 maja 1953 r., kiedy to w piśmie do dyrektora Biura ds. Funkcjonariuszy płk. Jerzego Siedleckiego przy jego nazwisku pojawia się adnotacja kpt. Kałkusa: „nie żyje” ${ }^{4}$. Na marginesie tego pisma nieznana ręka (Józefa Światły?) dopisała: „żyje i mieszka w Warszawie, kto tworzy tę legendę śmierci?"85.

Po ucieczce Światły „Orkan” mógł już spać spokojnie. 16 lutego 1954 r. Ludwik Sikora, starszy referent Wydziału I Departamentu „K” MBP, sporządził notatkę służbową, w której napisał: „Dotychczasowa współpraca z informatorem «Pióro» nie dała dobrych wyników, ponieważ figurant do rozpracowania [„Jesion”] zamieszkuje w Lublinie i informator «Pióro» nie ma możliwości kontaktowania się z nim. Wystąpienie $z$ wnioskiem o areszt Orkana-Łęckiego Tadeusza jest nieaktualne $z$ uwagi na jego zły stan zdrowia"86. Śledztwa w sprawie zbrodni „Orkana” nigdy nie wdrożono, chociaż jeszcze w roku 1968 władze SB ponownie przeglądały zarzuty stawiane mu przez Departament X MBP ${ }^{87}$. Zastępca „Łokietka” i zaufany człowiek Moczara dożył w spokoju co najmniej końca lat sześćdziesiątych. Pisywał wspomnienia, a w roku 1967 był autorem narracji do filmu o moczarowcach, zatytułowanego Blisko lasu ${ }^{88}$.

\footnotetext{
${ }^{82}$ Podpisał kpt. M. Kyzioł (AIPN, 703/1132, k. 192).

${ }^{83}$ Wynika to z zestawienia dwóch dokumentów: AIPN, 00945/170, Raport o zezwolenie na werbunek, k. 14, oraz ibidem, Zobowiązanie do współpracy, k. 16.

${ }^{84}$ AIPN, 703/1132, kopie: k. 178-180. Być może Kyziołowi chodziło o innego Tadeusza Łęckiego - „Żaka”, który istotnie zginął w czasie wojny, zob. Róg-Świostek, Czas przeszły i teraźniejszy, s. 60-62.

${ }^{85}$ AIPN, 703/1132, k. 173. Tym samym charakterem pisma napisano też w innym miejscu: „Czy Maj przesłuchiwany był na tę okoliczność, że meldował o tym wypadku komuś? I komu w KC o tym mówił?” (ibidem, Adnotacja z 5 VII 1951 r.), k. 161.

${ }^{86}$ AIPN, 00945/170, k. 49. 29 III 1954 r. ostatecznie wyłączono go z sieci tajnych współpracowników (ibidem, k. 52).

${ }^{87}$ Ibidem, k. 53-54. W roku 1975 jego akta sfilmowano.

${ }^{88}$ Wytwórnia „Czołówka”, 1967, konsultant: Marian Janic. O Janicu zob. też Róg-Świostek, Czas przeszły i teraźniejszy, s. 86.
} 


\section{Część II. Proces Tadeusza Maja}

\section{Formacja ideowa oddziału „Świt” w zeznaniach świadków}

W świetle wyjaśnień, jakie Maj składał nazajutrz po aresztowaniu ${ }^{89}$, w kwietniu 1944 r. dowodzony przez niego oddział bojowy „Świt” liczył 22 osoby ${ }^{90}$. Grupa zorganizowana została przez Eugeniusza Wiślicza-Iwańczyka jako jednostka bojowa organizacji pod tą samą nazwą; „Wiślicz” był jej założycielem. Dowódcą oddziału mianował właśnie Maja ${ }^{91}$, absolwenta szkoły podchorążych, byłego żołnierza ZWZ i AK ${ }^{92}$. Choć literatura wspomnieniowa okresu PRL ${ }^{93}$, szczególnie późnych lat sześćdziesiątych ${ }^{94}$, prezentowała „Świt” jako samorodny ruch proto-AL-owski, we wspomnieniach natrafia się na aluzje dotyczące niejasnej przeszłości Iwańczyka ${ }^{95}$ i ideologii jego oddziału. Tak scharakteryzował ją Tadeusz Maj:

linia ideologiczna organizacji „Świt” w tym okresie czasu w kwestii żydowskiej była taka sama jak w organizacji ZWZ. Ludzie przeszli do organizacji „Świt” z pewnym balastem zaczerpniętym w ZWZ z wrogiej propagandy [...], kiedy bowiem stanęła sprawa przeprowadzenia likwidacji grupy żydów [sic!, nad Kotyską, zob. dalej], nikt nie zaoponował przeciwko temu ${ }^{96}$.

\footnotetext{
${ }^{89}$ AAN, PG, 21/99, Protokół przesłuchania podejrzanego Tadeusza Maja, 26 V 1951 r.,
} k. 315 .

${ }^{90}$ Por., co o liczebności oddziału pisze Wiślicz-Iwańczyk, Echa Puszczy Jodłowej, s. 81: „Wiosną 1944 nasza starachowicka grupa AL rozrosła się do liczby co najmniej batalionu żołnierzy”. Zbieżność nazwy organizacji i oddziału partyzanckiego pod dowództwem „Łokietka” pozwalała Wiśliczowi-Iwańczykowi wyolbrzymiać liczebność grupy bojowej. Inni świadkowie liczebność oddziału „Świt” szacowali na trzydziestu żołnierzy, zob. na przykład APW, MBP, Protokół pprzesłuchania podejrzanego Jana Kozieła, 10 VI 1951 r., b.p.

${ }^{91}$ Wiślicz-Iwańczyk o Maju zob. idem, Echa Puszczy Jodłowej, s. 69, 132-134.

92 Większość członków grupy należała wcześniej do ZWZ, zob. na przykład AAN, PG, 21/99, Protokół przesłuchania świadka Bolesława Warszakowskiego, Warszawa, 13 IV 1951 r., k. 406.

${ }^{93}$ Zob. AAN, 8500, Akta osobowe Eugeniusza Wiślicza-Iwańczyka, „Działalność organizacji «Świt» i II Brygady AL Ziemi Kieleckiej na Kieleczczyźnie w latach 1942-1945”, maszynopis, $1968 \mathrm{r}$.

94 Józef Bolesław Garas, Oddziały Gwardii Ludowej i Armii Ludowej 1942-1945, Warszawa: Wydawnictwo MON, 1963, np. s. 232, 245; Wspomnienia żotnierzy GL i AL, oprac. Józef Bolesław Garas i in., Warszawa: Wydawnictwo MON, 1962, zob. tam wspomnienie Orkana-Łęckiego lub Roga-Świostka; II Kielecka Brygada AL „Świt”. Wspomnienia partyzantów, Warszawa: Wojskowy Instytut Historyczny, 1970; Mieczysław Wieczorek, Armia Ludowa. Działalność bojowa 1944-1945, Warszawa: Wydawnictwo MON, 1984, s. 94.

${ }^{95}$ Zob. na przykład AAN, 7774, Akta osobowe Adama Korneckiego, „Spadochroniarze” (maszynopis): „Wkrótce zapoznałem się z szefem Sztabu III Obwodu kpt. Wiśliczem [...]. Wiślicz przed wojną do ruchu rewolucyjnego nie należał $i$, jak mi powiedział, przypadkowo zupełnie zapoznał się z naszymi ludźmi” (k. 7).

${ }^{96}$ AAN, PG, 21/99, k. 323-324. Na rozprawie Maj zeznał, że „organizację ZWZ uważał [...] za lewicową" (ibidem, Protokół rozprawy głównej, 16 III 1954 r., k. 507). 
[R]ealizowałem wyraźne zarządzenie Iwańczyka Eugeniusza, który powiedział do mnie, że nie należy przyjmować do oddziału żydów. Zarządzenie to Iwańczyk wydał mi po fakcie zastrzelenia dwóch żydów [nad Kotyską] ${ }^{97}$.

Niepewni charakteru organizacji byli też sami jej członkowie. Jan Barszcz zeznał:

Wstępując do oddziału Łokietka [w maju 1944 r.], byłem przeświadczony, że jest to oddział Armii Ludowej, lecz później po upływie około dwóch miesięcy [...] dowiedziałem się, że prócz nazwy AL oddział nasz posiada nazwę „Świt”. [...] Pastuszko Edward [,Ptak”] komentował ten przydomek w ten sposób, że jest coś pokrewnego z organizacją $\mathrm{AK}^{98}$.

Dokładnie nazwy organizacji nie znałem, Dulka-Bakalarczyk powiedział mi tylko, że jest to organizacja wojskowa - chłopska ${ }^{99}$.

Z kolei sam założyciel „Świtu” uważał za naturalne, że „W odróżnieniu od elementu, którym dysponowała Gwardia Ludowa, elementu z natury rzeczy nieposiadającego większego wykształcenia, uważano nas za grupę inteligencką"100.

To, że stosunek „świtowców” do Żydów był co najmniej ambiwalentny, sugerują losy dwojga lekarzy narodowości żydowskiej, dr. Adama (N.N.) i jego żony, dr Ireny ${ }^{101}$, przydzielonych do oddziału Maja we wrześniu 1944 r. O ich istnieniu dowiadujemy się z zeznań członka oddziału „Świt”, Józefa Bugajskiego:

We wrześniu 1944 [...] do brygady przydzieleni zostali chirurg i doktorka narodowości żydowskiej, do których Łokietek z miejsca odniósł się wrogo, przejawiało się to $\mathrm{w}$ ignorancji [ignorowaniu] wymienionych osób, ośmieszaniu ich przed innymi, a kiedy chirurg zwrócił się do Łokietka z prośbą o przydzielenie mu pistoletu, Łokietek ze śmiechem prośbie odmówił. O powyższym mówił mi sam chirurg, użalając się na postępowanie Łokietka odnośnie [do] jego osoby oraz owej doktorki, która była żoną chirurga. [...] Szykany ze strony Łokietka i Orkana ${ }^{102}$, opowiadanie różnych sprośnych

${ }^{97}$ Ibidem, Protokół przesłuchania podejrzanego Tadeusza Maja, 27 V 1951 r., k. 332.

${ }^{98}$ Ibidem, Protokół przesłuchania świadka Jana Barszcza, 16 III 1950 r., k. 378.

${ }^{99}$ Ibidem, Protokół przesłuchania świadka Wacława Tracza, 27 III 1951 r., k. 399. Na przesłuchaniu Bakalarczyk zamiast 1944 podał 1943 r. (ibidem, Protokół przesłuchania świadka Adama Bakalarczyka, Warszawa, 16 II 1954 r., k. 454; por. Wiślicz-Iwańczyk, Echa Puszczy Jodłowej, s. 142).

${ }^{100}$ AAN, 8500, Akta osobowe Eugeniusza Wiślicza-Iwańczyka, „Działalność organizacji «Świt» i II Brygady AL Ziemi Kieleckiej na Kieleczczyźnie w latach 1942-1945”, maszynopis, 1968 r., s. 25.

${ }^{101}$ Wiślicz-Iwańczyk na ich temat: „Trzeba powiedzieć, że felczerzy i lekarze narodowości żydowskiej byli nieocenieni, leczyli partyzantów z wielkim zapałem. Znałem jeszcze dwoje innych - było to małżeństwo - niestety zginęli podczas wojny podczas przechodzenia przez front na Wiśle” (ibidem, „Działalność AL na Kielecczyźnie”. Relacja Eugeniusza Iwańczyka-Wiślicza nagrana w Zakładzie Historii Partii 9 IX 1965 r., k. 122.

${ }^{102}$ Fakty te świadek potwierdził na rozprawie (AAN, PG, 21/99, Sąd Wojewódzki m.st. Warszawy, Protokół rozprawy głównej, 27 III 1954 r., k. 513; o zachowaniu Maja zob. też 
kawałów w ich obecności i używanie plugawych określeń miało na celu wygnanie tych ludzi z oddziału, co też ostatecznie zostało dokonane i oddział oni opuścili przypuszczalnie w połowie października 1944 i jak mi jest wiadomym, obie te osoby zginęły podczas przedzierania się przez front w okolicy Baranowa, Sandomierza ${ }^{103}$.

Informacje te potwierdził Jan Kozieł:

stosunek członków oddziału do żydów nie był przyjazny, a raczej wrogi. [...] Latem 1944 roku do naszego oddziału przybyło dwoje ludzi. Byli to lekarze, prawdopodobnie narodowości żydowskiej. Pseudonim mężczyzny był Adaś, kobietę nazywano Irka. Wywiązywali się oni bardzo dobrze ze swoich obowiązków. Słyszałem, że gdy oddział nasz przechodził przez front, Irka została zabita, zaś Adaś zastrzelił się sam¹04.

\section{Oddziat „Świt”, jego skład i miejsca stacjonowania}

Maj podał, że wiosną 1944 r. zaraz po sformowaniu grupę połączono z oddziałem GL pod dowództwem Czesława Byka Boreckiego „Brzozy”105. Składał się wówczas z dwu drużyn, dowódcą pierwszej był Jan Pocheć „Sosna” ze Świśliny koło Starachowic, drugiej - Dziubiński „Dąb” (wkrótce zginął). Pytany o innych członków oddziału, Maj wymienił:

ibidem, Zeznanie płk. Bronisława Jaworskiego „Michała”, k. 520: „Lekarz i jego żona skarżyli się do mnie na specyficzny stosunek do nich wszystkich członków oddziału, jak i oskarżonego, który miał odmówić dania im broni”, zob. dalej.

${ }^{103}$ AAN, PG, 21/99, Protokół przesłuchania świadka Józefa Bugajskiego, 22 IX 1949 r., k. 376. Na procesie Jana Kozieła w styczniu 1954 r. Bugajski sformułował to inaczej: „Stosunek do tego lekarza żydowskiego był dobry, jednak pod koniec zastępca dowódcy [„Orkan”] wytworzył niewłaściwy stosunek do nich, wskutek tego lekarz wraz z żoną przeniósł się do innego oddziału, gdzie później zginął” (APW, SW, IV3K.126/53, Protokół rozprawy głównej przeciwko Janowi Koziełowi, 23 I 1954 r., k. 44).

${ }^{104}$ APW, MBP, Protokół przesłuchania podejrzanego Jana Kozieła, 10 VI 1951 r., b.p. Na kolejnym przesłuchaniu 23 VI 1951 r. Kozieł dodał, że przez front przechodzili oni w październiku 1944 „Z grupą Orkana-Łęckiego Tadeusza”.

${ }^{105}$ Zob. AAN, 8181, Akta osobowe Czesława Byka-Boreckiego, k. 4: „W końcu kwietnia dołączyła do mojego oddziału grupa «Świtu» w sile 20 ludzi pod dowództwem Łokietka w okolicy Sienna. [następuje opis akcji wykolejenia pociągu koło Kunowa] Na drugi dzień po tej akcji raniony został, a później dobity partyzant Maks z mojego oddziału przez oddział AK w miejscowości (majątek Grzegorzewice), w odwecie spalony został majątek i zlikwidowane dwie właścicielki”. Zob. Wieczorek, Armia Ludowa..., s. 290, 340-345, 417. Borecki początkowo kierował PUBP w Radomiu, następnie MUBP w Kielcach, potem zaś WUBP w Kielcach i Zielonej Górze, za: Wokót pogromu kieleckiego, t. 2, s. 95. W okresie jego pracy w Radomiu i Kielcach oskarżano go o liczne nadużycia i rabunki, między innymi o to, że „zostało wykopane złoto w getcie, też to zostało rezebrane między siebie”; AIPN, 03/1132, Protokół przesłuchania świadka Czerwińskiego, k. 71; ibidem, Notatka oficera decyzyjnego, k. 73: „Powracać do spraw podanych przez Czerwińskiego [...] uważam z niecelowe”. 
1) Bakalarczyk Adam ps. Dulka z Rzeczniowa, 2) Maj Jan ps. Sęk z Rzeczniowa, 3) Węgrzecki Edward [„Komar”] z Rzeczniowa (nie żyje), 4) Ołowiak Ireneusz [„Huragan”] z Rzeczniowa (nie żyje), 5) Maj Bolesław z Rzeczniowa (nie żyje), 6) [Bolesław] Warszakowski z Rzeczniowa [„Jeleń”], 7) Tracz Wacław ps. Skóra z Rzeczniowa, 8) Bugajski Józef ps. Azja z Rzeczniowa, 9) Józef Pyrciak ps. Pocisk z kol[onii] Grochów k. Rzeczniowa (nie żyje), 10) ps. Kruk z Jasieńca [Iłżeckiego], nazwiska nie pamiętam, oraz szereg innych osób ${ }^{106}[\ldots$. ]. Po powrocie $z$ lasów janowskich [oddział udał się tam w maju 1944 r. w celu zaopatrzenia się w broń ze zrzutów radzieckich - J. T.-B.] ${ }^{107}$ oddział podlegał bezpośrednio Wiśliczowi Eugeniuszowi, z którym utrzymywany był kontakt przez gońców lub przyjeżdżał bezpośrednio do oddziału ${ }^{108}$.

Wśród miejsc stacjonowania w okresie pomiędzy powrotem z Lasów Janowskich do chwili utworzenia II Brygady AL „Świt”, Maj zeznał, że przebywali między innymi: na początku lipca w Kotysce koło Jasieńca Iłżeckiego ${ }^{109}$, zaraz potem w Piotrowym Polu koło Borsuk i na początku sierpnia w leśniczówce Lipie koło Wierzbnika ${ }^{110}$. W każdym z tych miejsc doszło do mordów na Żydach.

${ }^{106}$ Na przykład Władysław Dąbrowski, Wincenty Krzos, Jan Zaremba „Okrutny”, Stanisław Chmurzyński „Topór”, Edward Pastuszko „Ptak”, Jan Kozieł „Galant” z Iłży (zob. Wiślicz-Iwańczyk, Echa Puszczy Jodłowej, s. 136) i N.N. „Smotek” ze Starachowic (AAN, PG, 21/99, Protokół przesłuchania podejrzanego Tadeusza Maja, 27 V 1951 r., k. 332). Zeznający w roku 1949 Józef Bugajski „Azja” rozszerzył skład oddziału, podając kolejne pseudonimy: „Grom” (Jan Stanecki?, za: Wiślicz-Iwańczyk, Echa Puszczy Jodłowej, s. 135) i „Zapałka” (Jan Świtek, za: ibidem, s. 135, lub Jan Latała, za: ibidem, s. 260), zob. AAN, PG, 21/99, k. 371. Zeznający w 1951 r. Jan Barszcz dodał jeszcze następujące osoby: „Przychodni” („obecnie pracuje w Komisji Specjalnej w Kielcach”), Edward Konopski „Ząbek” z Milanówka k. Warszawy, „rozstrzelał go własnoręcznie z automatu Orkan” (ibidem, k. 381), zob. dalej. Wiślicz-Iwańczyk (Echa Puszczy Jodłowej, s. 134-135) dodaje jeszcze Tadeusza Borka „Wywrota”. Podaje też nazwisko „Przychodniego”, adiutanta Tadeusza Maja - [Stanisław] Rokita (s. 201). W zeznaniach Tracza pojawia się jeszcze Teodor Stępień „Glina” (AAN, PG, 21/99, Protokół przesłuchania świadka Wacława Tracza, Warszawa, 27 III 1951 r., k. 400).

${ }^{107}$ Maj połączył się wówczas z oddziałami dowodzonymi przez Brzozę-Boreckiego oraz ludzi o pseudonimach „Wrzos” i „Góral” (ibidem, k. 399).

${ }^{108}$ AAN, PG, 21/99, Protokół przesłuchania podejrzanego Tadeusza Maja, 27 V 1951 r., k. 316.

109 „W zagajniku z gęstej świerczyny mieliśmy porobione z gałęzi budy, które służyły do ochrony przed deszczem. Budy nasze były w zagajniku rozrzucone na przestrzeni mniej więcej 100 m kw., dookoła były rozstawione cztery czy pięć posterunków” (ibidem, Protokół przesłuchania świadka Jana Barszcza, Starachowice, 16 III 1951 r., k. 382).

${ }^{110}$ AAN, PG, 21/99, k. 316. 
Kotyska $a^{111}$

Podczas pierwszego przesłuchania po aresztowaniu Tadeusz Maj następująco opisał okoliczności morderstwa:

W miesiącu lipcu $1944^{112}$ [...] przyszła grupa, składająca się z około $10^{113}$ osób narodowości żydowskiej (w tym jedna kobieta) ${ }^{114}$. Grupę tę przyprowadził ps. Szczęśliwy ${ }^{115}$ z zamiarem przyłączenia jej do oddziału. Z ps. Szczęśliwym uzgodniłem, że zostaną oni wszyscy przyjęci do oddziału. W tym czasie do oddziału przyjechał Sobczyński Władysław razem z Wiśliczem Eugeniuszem, którzy zapytywali mnie, co ta grupa robi koło oddziału. Oświadczyłem im, że chcą oni wstapić do naszego oddziału, informując, że przyprowadził ich Szczęśliwy ${ }^{116}$, który od trzech dni był już u mnie w oddziale. Na to Sobczyński Władysław powiedział, że trzeba ich wszystkich zlikwidować. Wiślicz podkreślił, że znajdują się wśród nich Żydzi z Iłży, którzy znają ludzi z oddziału i mogą zadenuncjować nasz oddział, podając rysopisy ww. Sobczyński zaznaczył przy odjeździe, że całą grupę należy bezwględnie zlikwidować. Po odjeździe Sobczyńskiego W. i Wiślicza E. wybrałem sobie grupę ludzi do pomocy z automatami, tj. Bakalarczyka Adama ps. Dulka ${ }^{117}$, Tracza Wacława ps. Skóra oraz innych, których nazwisk nie przypominam sobie $^{118}$. Wraz z ww. udaliśmy się do grupy Żydów i zażądałem od nich złożenia

${ }^{111}$ Kotyska to rzeka przepływająca w pobliżu miejsca opisywanego zdarzenia, a także wzgórze o tej samej nazwie, zob. Heda, Wspomnienia „Szarego”, s. 69.

${ }^{112}$ Datę i liczbę napotkanych Żydów (,,jedenastu Żydów i jedna Żydówka”) potwierdza też zeznanie Józefa Bugajskiego z 20 IX 1949 r. (AAN, PG, 21/99, Protokół przesłuchania świadka Józefa Bugajskiego, 22 IX 1949 r., k. 370).

${ }^{113}$ W zeznaniu z 27 V 1951 r. Maj podaje liczbę 12 osób (ibidem, Protokół przesłuchania podejrzanego Tadeusza Maja, 27 V 1951 r., k. 328).

${ }^{114}$ Była to grupa, która zbiegła ze starachowickiego obozu pracy, od kwietnia słabo pilnowanego przez Niemców (ibidem). Fakt ten potwierdzają wszyscy zeznający w sprawie.

${ }^{115}$ Zob. na jego temat w sekcja „Sprawa «Ząbka»”.

${ }^{116}$ Jeden z Żydów „obrał sobie pseudonim Szczęśliwy, był wzrostu średniego, był w białej bluzie sportowej, buty oficerki z grubej skóry i spodnie do butów - bryczesy" (AAN, PG, 21/99, Protokół zeznania świadka Jana Świtka, 21 III 1951 r., k. 393-394). O butach „Szczęśliwego" zob. w sekcji „Sprawa «Ząbka»”.

${ }^{117}$ Następnie zeznał, że polecił Bakalarczykowi dobrać ludzi do tej akcji (AAN, PG, 21/99, Protokół przesłuchania podejrzanego Tadeusza Maja, 28 V 1951 r., k. 336).

11827 V 1951 r. wymienił jeszcze Edwarda Pastuszkę „Ptaka” i N.N. „Smotka” (AAN, PG, 21/99, k. 326), Jana Kozieła „Galanta” i Jana Maja „Sęka” (ibidem, k. 332). Przesłuchiwany 30 III 1953 r. dodał ponadto Józefa Bugajskiego „Azję” (ibidem, k. 366). Zob. też ibidem, Protokół przesłuchania świadka Józefa Bugajskiego, 22 IX 1949 r., k. 370. Jan Świtek w grupie strzelających wymienił Maja, Bakalarczyka, Kozieła, Tracza, N.N. „Smotka” i adiutanta „Wiślicza” - „Ząbka” (ibidem, Protokół zeznania świadka Jana Świtka, 21 III 1951 r., k. 383). Warszakowski w grupie rozstrzeliwujących wymienił Bakalarczyka, Tracza i Tadeusza Borka „Wywrota” (ibidem, Protokół przesłuchania świadka Bolesława Warszakowskiego, Warszawa, 13 IV 1951 r., k. 410. Z kolei Jan Kozieł jako wykonawców wyroku wskazał siebie, Bakalarczyka, Tracza, Tadeusza Borka „Wywrota”, N.N. „Smotka”, N.N. „Trzcinę” oraz „Łokietka” (APW, MBP, Protokół przesłuchania podejrzanego Jana Kozieła, 10 VI 1951 r., b.p.). 
wszystkich pieniędzy i wartościowych przedmiotów. Po złożeniu żądanych przedmiotów przeprowadziliśmy u ww. rewizję, znajdując u jednego pienią$\mathrm{dze}^{119}$. Ww. był podany w rysopisie przez Wiślicza. Do ww. oddałem strzał z pistoletu typu vis, trafiając go w głowę. Upadł na miejscu. Wtenczas drugi stojący obok niego wystąpił, mówiąc do mnie „strzelaj mnie też”. Na to ja oddałem do ww. strzał w głowę, zabijając go na miejscu. Pozostałym rozkazałem się rozebrać i złożyć ubranie, co też oni uczynili. Nadmieniam, że nie wszyscy byli w bieliźnie, ponieważ zabierano te części garderoby, które nadawały się do noszenia ${ }^{120}$. Po zabraniu im odzieży kazałem im uciekać, polecając swoim ludziom strzelać za uciekającymi w górę. Sam również strzelałem. Nie wykluczam możliwości zastrzelenia uciekających przez ludzi, którzy byli ze mną ${ }^{121}$. W okresie tygodnia czasu spotkałem się z Sobczyńskim Władysławem, który robił mi wymówkę, dlaczego nie zlikwidowałem na miejscu całej grupy Żydów ${ }^{122}$.

Na pytanie oficera, próbującego jako powód rozstrzelania podpowiedzieć współpracę obu zabitych Żydów „z Gestapo”, Tadeusz Maj podkreślił dobitnie, że współpraca z Niemcami „nie był[a] zasadniczą przyczyną. Od Sobczyńskiego otrzymałem rozkaz zlikwidowania całej grupy żydowskiej”123. Niezakwestionowa-

${ }^{119}$ Był to ,jeden banknot pieniężny polski” (AAN, PG, 21/99, Protokół przesłuchania podejrzanego Tadeusza Maja, 27 V 1951 r., k. 330). W kolejnym zeznaniu doprecyzował, że było to „zdaje się 500 zł zaszyte w marynarce”. Po dwóch latach (30 III 1953 r.) nie wykluczał, że był to banknot dolarowy. Zob. zeznanie Tracza: „Wówczas jeden Żyd zgłosił, że ma zaszyte pieniądze w marynarce. Łokietek wówczas powiedział, że za to, że nie powiedział od razu o tym fakcie ukrytych pieniędzy, zostanie rozstrzelany" (ibidem, Protokół przesłuchania świadka Wacława Tracza, Warszawa, 27 III 1951 r., k. 399). Z omawianej przez Browninga relacji Lejba Fajntucha zarysowuje się następujący obraz tego zdarzenia: „niewielka grupka uciekinierów skontaktowała się wówczas z oddziałem partyzanckim, który zapewnił, że przyjmie Żydów. Zamiast tego Żydzi zostali zmuszeni do oddania wszystkich wartościowych rzeczy, a Żyd, u którego znaleziono zaszyty w ubraniu banknot, został zastrzelony. Pozostałym kazano uciekać w rozproszeniu. Lejb z bratem udali się na wschód. Po drodze pomagali im różni ludzie, aż 15 sierpnia przedostali się na sowiecką stronę” (Browning, Remembering Survival..., s. 249-250).

120 „Łokietek rozkazywał, kto ma co zdjąć” (AAN, PG, 21/99, Protokół przesłuchania świadka Wacława Tracza, Warszawa, 27 III 1951 r., k. 402. „[K]rążyły pogłoski, że wszyscy oni zostali rozebrani i Łokietek po dwoje rozkazywał im uciekać pod górkę w krzaki tarniny i potem do uciekających strzelano" (ibidem, Protokół przesłuchania świadka Bolesława Warszakowskiego, Warszawa, 13 IV 1951 r., k. 412). „Złożone przez żydów pieniądze i biżuterię przeliczał Dulka-Bakalarczyk i zdaje się Bugajski Józef [...]. Co zrobiono z biżuterią i pieniędzmi, nie jest mi wiadomo" (ibidem, Protokół przesłuchania świadka Wacława Tracza, Warszawa, 27 III 1951 r., k. 403).

${ }^{121}$ „W trakcie ucieczki i strzelania widziałem, że jeden z uciekających upadł, lecz podniósł się i biegł dalej [...] nie wykluczam [...] że kilka osób mogło być zabitych” (ibidem, Protokół przesłuchania podejrzanego Tadeusza Maja, 27 V 1951 r., k. 331).

${ }^{122}$ Ibidem, Protokół przesłuchania podejrzanego Tadeusza Maja, 26 V 1951 r., k. 318-319.

${ }^{123}$ Oskarżenie Sobczyńskiego i Wiślicza-Iwańczyka podtrzymał także w kolejnych dniach, zob. ibidem, Protokół przesłuchania podejrzanego Tadeusza Maja, 27 V 1951 r., k. 328, 335, 
nie rozkazu Sobczyńskiego tłumaczył tym, że „uważany był [on za] rzecznik[a] NKWD, który przybył z ZSRR [a zatem] reprezentuje właściwy kierunek polityczny”124. Na zakończenie powtórzył znów zdanie o roli „Wiślicza”: „Wiślicz dodał, że dwóch Żydów z Iłży, którzy rzekomo mieli znać wszystkich ludzi w oddziale, z tego tytułu mogą być dla nas niebezpieczni. Takie naświetlenie przez Wiślicza uważam jako pretekst do upozorowania morderstwa"125.

Dopiero dwa lata później Maj zaczął zeznawać, że człowiekiem, na którego likwidację Wiślicz nalegał szczególnie, był niejaki Kamiński z Iłży ${ }^{126}$. Wprawdzie nazwisko to wymienił już Bakalarczyk, ale jak widzieliśmy, „argument szpiegowski” Maj z początku zdecydowanie odrzucał. Od roku 1953 nazwisko Kamińskiego coraz częściej pojawiało się w aktach ${ }^{127}$. Hipotezą o ewentualnej współpracy owego Kamińskiego z gestapo funkcjonariusze MBP intensywnie zajęli się dwa lata później, i choć jej nie udowodnili, doprowadziło to w końcu do przedterminowego zwolnienia Maja i rewizji nadzwyczajnej wyroku.

Tymczasem jednak w trakcie intensywnych przesłuchań w roku 1951 Maj wzbogacił swoje zeznanie o drastyczne szczegóły egzekucji nad Kotyską. Opowiedział na przykład o rozmowie z młodą dziewczyną, która była w grupie rozstrzelanych ${ }^{128}$.

W rozmowie z nią w sposób ubliżający wypytywałem ją, czy jest panną, czy miała stosunki z mężczyznami i którego z nas chciałaby za kawalera. Kobieta ta na skutek nieśmiałości ociągała się z odpowiedzią, wówczas zagroziłem jej, jeśli nie odpowie na moje pytania, to ją zastrzelę i w obawie przed tym kobieta wybrała sobie mnie za kawalera ${ }^{129}$.

a także dwa lata później, ibidem, Protokół końcowego przesłuchania podejrzanego Tadeusza Maja, Warszawa, 20 V 1953 r., k. 416.

${ }^{124}$ Ibidem, Protokół przesłuchania podejrzanego Tadeusza Maja, 22 V 1951 r., k. 322. „Sobczyńskiego nie znałem, więc Iwańczyk przedstawił mi go jako rzecznika radzieckiego NKWD” (ibidem, Protokół przesłuchania podejrzanego Tadeusza Maja, 27 V 1951 r., k. 328).

${ }^{125}$ AIPN, 703/1132, Przesłuchanie podejrzanego Tadeusza Maja, 26 V 1951 r., k. 94.

${ }^{126}$ AAN, PG, 21/99, Protokół przesłuchania podejrzanego Tadeusza Maja, 30 III 1953 r., k. 366. Słowa Wiślicza-Iwańczyka przytoczone w: ibidem, Protokół końcowego przesłuchania podejrzanego Tadeusza Maja, Warszawa, 20 V 1953 r.: „żebyście nie pominęli tego małego Kamińskiego z Iłży, który mnie dobrze zna i zna jeszcze innych”, k. 416.

${ }^{127}$ Nazwisko to zostało wymienione w skardze żony Maja Eugenii, którą skierowała ona do Franciszka Jóźwiaka, 21 III 1953 r. (AAN, PG, 21/99, k. 90).

${ }^{128}$ Zeznanie Tracza na jej temat: „Żydówka miała na sobie zieloną sukienkę i zdaje się w niej pozostała” (AAN, PG, 21/99, Sąd Wojewódzki m.st. Warszawy, Protokół rozprawy głównej przeciwko Tadeuszowi Majowi, 27 III 1954 r., k. 516).

${ }^{129}$ Ibidem, Protokół przesłuchania podejrzanego Tadeusza Maja, 27 V 1951 r., k. 326. „Rozmowa prowadzona przez Łokietka miała charakter szyderczy i ubliżający godności czlowieka. Np. [...] prowadził rozmowę z kobietą z tej grupy. Pytał jej się, czy jest panną, czy miała już stosunki z mężczyzną, kogo by sobie w tej chwili zechciała wybrać na kawalera z jego ludzi itd. Pytania te wywołały wśród ludzi z grupy Łokietka wybuchy śmiechu. Kiedy kobieta powodowana nieśmiałością i wstydem nie odpowiadała na pytania Łokietka, ten zagroził jej, że gdy nie odpowie [...] to ją zastrzeli. Wówczas kobieta ta powiedziała, że 
Kobieta żydowska prosiła mnie, abym pozwolił jej iść razem z bratem, na co nie zgodziłem się, tylko kazałem jej uciekać samej ${ }^{130}$.

20 kwietnia 1949 r. w Marculach oficer MBP odebrał zeznanie od leśniczego Józefa Giemzy z Małuszyna ${ }^{131}$. Potwierdził on słowa Maja o tym, że w czasie pierwszego spotkania ze „świtowcami” pod Kotyską nie zastrzelono wszystkich Żydów. Zbiegowie z obozu w Starachowicach od dawna ukrywali się w okolicy Jasieńca Iłżeckiego. Pobudowawszy sobie bunkry w lesie, w zamian za utrzymanie pomagali chłopom przy robotach w polu.

Przed samymi żniwami przyszło do mnie do mieszkania dwóch żydków z tej grupy [...] i prosili mnie o żywność. [...] Jeden $\mathrm{z}$ nich [...] w wieku około 30 lat miał rękę ustrzeloną i zaczął się do mnie żalić, że w nocy zabrali ich partyzanci [...]. Następnie [...] partyzanci ci wyprowadzili ich w las za miejscowość Kotyska Pogórze (tj. oddział nr 155 ${ }^{132}$ ) i tam kazali im uciekać całą grupa, a oni zaczęli do nich strzelać. Co się stało z pozostałymi żydkami, on mi nie mówił, gdyż jak tłumaczył [...], ustrzelono mu jedną rękę i jemu udało się uciec, a pozostałych, on przypuszcza, że zostali zastrzeleni. Żydek ten po przestrzeleniu udał się do miejscowości Lipie i tam ob[ywatelka] Jankowska, która ma syna Edwarda, zrobiła mu opatrunek. Następnie żydek ten już z zabandażowaną ręką przyszedł do mnie po chleb. Żydek ten opowiadał mi, że w godzinach wieczornych zabrało ich kilku partyzantów i oświadczyli im, że zabiera[ją] ich do oddziału partyzanckiego, a następnie zaczęli do nich strzelać. Po wyjściu tego żydka z mojego mieszkania ja ich więcej nie widziałem. Po upływie dłuższego czasu ja, przechodząc przez oddział nr 155, zauważyłem odkopane przez lisy trupy pomordowanych ludzi. Jak się zorientowałem, to trupy te leżały pod górą ${ }^{133}$ około zakrętu rzeczki, tam gdzie opowiadał mi o tym zajściu żydek, który miał przestrzeloną rękę [...] ${ }^{134}$.

wybiera sobie Łokietka. Łokietek wtedy splunął tylko i powiedział w wulgarny sposób, że jej nie potrzebuje" (ibidem, Protokół przesłuchania świadka Bolesława Warszakowskiego, Warszawa, 13 IV 1951 r., k. 406). Zdarzenie to Maj potwierdził w: ibidem, Protokół końcowego przesłuchania podejrzanego Tadeusza Maja, Warszawa, 20 V 1953 r., k. 418. Zeznanie Warszakowskiego na ten temat: „słyszałem żartobliwą rozmowę z Żydówką. Łokietek pytał ją, czy ma męża (ibidem, Sąd Wojewódzki m.st. Warszawy, Protokół rozprawy głównej, 27 III 1954 r., k. 517).

${ }^{130}$ Ibidem, Protokół przesłuchania podejrzanego Tadeusza Maja, 28 V 1951 r., k. 336. Wacław Tracz: „Kiedy żydówka zwróciła się z prośbą do Łokietka, by jej zezwolił iść razem z bratem, Łokietek nie zgodził się i musiała iść sama” (ibidem, Protokół przesłuchania świadka Wacława Tracza, Warszawa, 27 III 1951 r., k. 403).

${ }^{131}$ Jako współpracownika wspomina go Wiślicz-Iwańczyk, Echa Puszczy Jodłowej, s. 137.

${ }^{132}$ Oznaczenie kwadratu leśnego.

${ }^{133}$ Por. przytaczana już wypowiedź: „Łokietek po dwoje rozkazywał im uciekać pod górkę w krzaki tarniny i potem do uciekających strzelano” (AAN, PG, 21/99, Protokół przesłuchania świadka Bolesława Warszakowskiego, Warszawa, 13 IV 1951 r., k. 412). Por. też wypowiedź leśniczego Giemzy w sekcji „Mężczyźni i kobiety”.

${ }^{134}$ Ibidem, Protokół przesłuchania świadka Józefa Giemzy, 20 IV 1950 r., k. 376; ibidem, Protokół przesłuchania świadka Bolesława Warszakowskiego, Warszawa, 13 IV 1951 r., 
Potwierdzenie, że Żydzi zostali rozstrzelani po tym, jak zrobiono im nadzieję na przyjęcie do oddziału, znajdujemy w zeznaniu Jana Barszcza z 1951 r. Opowiadał on, że początkowo do oddziału zgłosiło się „dwóch czy też jeden żyd”, który po rozmowie z Łokietkiem został przydzielony do grupy. „Przez dwa dni był on w naszym oddziale, spał razem ze mną, wyrażał duże zadowolenie z tego, że został przyjęty, i opowiadał, że dowództwo oddziału zgodziło się na sprowadzenie jego znajomych” ${ }^{35}$. Po dwóch dniach przyjęty przez „Łokietka” Żyd „istotnie przyprowadził grupę ludzi narodowości żydowskiej w liczbie dziesięć-dwanaście osób [...], wszyscy wyglądali dobrze, tzn. byli dobrze ubrani”"136. W pewnej odległości od oddziału kazano im czekać na decyzję dowództwa. Barszcz zeznał, że w tym samym czasie do oddziału „przyjechał Wiślicz rowerem i w szałasie Łokietka był około godziny”137. Nie wiedział, o czym rozmawiali, stwierdził tylko, że po zakończonej rozmowie z szałasu „Łokietek” wyszedł z „Wiśliczem”, Dulką-Bakalarczykiem oraz Edwardem Konopskim „Ząbkiem” i udali się do oczekującej grupy Żydów. Po upływie około półgodziny świadek usłyszał serie wystrzałów z automatu i kilka strzałów pojedynczych, po czym wszystko ucichło. „Nadmieniam, że w całym oddziale było zaniepokojenie z powodu tych strzałów, myślano, że może Niemcy otaczają oddział”.

Tej samej nocy oddział wyruszył w kierunku wsi Piotrowe Pole, odległej o mniej więcej 14 kilometrów od Kotyski. Barszcz opowiadał dalej:

W drodze gdyśmy maszerowali, Galant - Kozieł Jan opowiadał mi, że wszyscy żydzi, którzy chcieli wstapić do naszego oddziału, zostali „rozłupani”, tj. rozstrzelani ${ }^{138}$. [...] W dzień zaobserwowałem, że niektórzy z naszych ludzi mają inne ubrania i buty. Na przykład dokładnie rozpoznałem spodnie, które miał Tracz Wacław ps. Skóra na sobie, były one na niego trochę za ciasne. Zresztą on sam, tj. Tracz Wacław, ze śmiechem pokazywał mi te spodnie, mówiąc: „patrz, to po tych żydach, którzy mieli być przyjęci do oddziału”. Ząbek również miał na sobie oficerki po żydach, oraz wielu innych, przeważnie ludzie z Rzeczniowa, z którymi Maj wyraźnie sympatyzował' ${ }^{139}$.

k. 406. Być może rannym był Lejb Fajntuch, jego brat lub któryś z jego towarzyszy, zob. przypis 119.

${ }^{135}$ Ibidem, Protokół przesłuchania świadka Jana Barszcza, Starachowice, 16 III 1950 r., k. 383. Ciała dwóch Żydów zastrzelonych osobiście przez Tadeusza Maja nad Kotyską zostały pochowane przez Bolesława Warszakowskiego i Jana Maja-Sęka (ibidem, Protokół przesłuchania świadka Bolesława Warszakowskiego, Warszawa, 13 IV 1951 r., k. 411).

${ }^{136}$ Ibidem, Protokół przesłuchania świadka Jana Barszcza, 16 III 1953 r., k. 383.

${ }^{137}$ Ibidem.

${ }^{138}$ Są to niemal te same słowa, które Jan Kozieł włożył w usta „Smotka”, zob. dalej: APW, SW, IV3K.126/53, Protokół rozprawy głównej przeciwko Janowi Koziełowi, 13 III 1954 r., k. 60.

${ }^{139}$ AAN, PG, 21/99, Protokół przesłuchania świadka Jana Barszcza, 16 III 1953 r., k. 384. 


\section{Piotrowe Pole}

Z dalszego ciągu zeznania Jana Barszcza wynika, że drugi wypadek mordowania Żydów zdarzył się zaraz potem, w chwili gdy oddział przez jeden dzień kwaterował we wsi Piotrowe Pole. Morderstwa tego dokonali nieznany z nazwiska członek „Świtu” o pseudonimie „Smotek”, „znany ogólnie z tego, że nie lubił żydów”, i Jan Kozieł „Galant”. Barszcz oznajmił, że „Smotek” zupełnie otwarcie opowiadał o morderstwie, dodając, że zdobyli „dużo pieniędzy i złota”. Po wypadku tym osobiście widział u „Smotka” i „Galanta” „dużo pieniędzy papierowych. Złota nie widziałem u ww., przypominam sobie jednak, że Smotek miał po tym wypadku jakiś naszyjnik prawdopodobnie wysokiej wartości. Według oświadczenia Smotka, morderstw tego dokonali oni z własnej inicjatywy. Sprawa ta była jednak tak głośna w oddziale, że nie mogła ona ujść uwadze dowództwa"140.

Tadeusz Maj nie zaprzeczył, że słyszał o zabójstwach, jakich członkowie jego oddziału dokonywali na własną rękę (przypisywał je demoralizacji spowodowanej rozstrzelaniem Żydów nad Kotyską, czuł się za nią odpowiedzialny ${ }^{141}$ ), nie wiadomo jednak, czy miał na myśli to samo zdarzenie, które zrelacjonował Barszcz. Tydzień po akcji nad Kotyską miał mu o nim mówić Orkan-Łęcki: „opowiadał mi, że ps. Smotek [...] [...] z ps. Ptak - [Edwardem] Pastuszką dokonali zabójstwa jednego Żyda na terenie lasów starachowickich” ${ }^{142}$. Dwa lata później Maj dodał jeszcze w tej sprawie:

Słyszałem [...], że jeden z podległych mi partyzantów, wracając z jakiegoś zadania, spotkał w lesie grupę osób pochodzenia żydowskiego, tych samych, którzy byli w lesie koło Kotyski. Ilu tam ich było, tego dokładnie nie pamiętam. By partyzant ten, używający ps. Smotek, dokonał zabójstwa tych osób, tego nie wiem. Znając jednakże charakter Smotka, należy przyjąć, że dokonał on zabójstwa tych osób, ponieważ opowiadając partyzantom o spotkaniu z tymi osobami, Smotek dziwnie uśmiechał się ${ }^{143}$.

W procesie Jana Kozieła, oskarżonego o udział w zbrodni w Piotrowym Polu, Jan Barszcz staranniej dobierał słowa:

Przypominam sobie, że zginęło wtedy [tzn. w Piotrowym Polu] kilku żydów. Słyszałem tylko, że ps. Smotek, Tracz [„Skóra”], Dulka [Adam Bakalarczyk],

\footnotetext{
${ }^{140}$ Ibidem, k. 385-386.
}

${ }^{141}$ Słusznie, jak wynika z następującej wypowiedzi Jana Kozieła: „Dokonując morderstwa, kierowałem się przede wszystkim rozkazem [...]. Z drugiej strony miałem na myśli niedawno widziany obraz likwidacji ludności żydowskiej nad Kotyską, gdzie sam dowódca oddziału bojowego «Świt» - Maj Tadeusz ps. Łokietek własnoręcznie rozstrzeliwał, to też wpłynęło na to, że wytworzyłem sobie pogląd, że ludność narodowości żydowskiej należy likwidować” (AIPN, 00945/170, Protokół zeznania podejrzanego Jana Kozieła, niedatowany odpis, k. 31).

${ }^{142}$ AAN, PG, 21/99, Protokół przesłuchania podejrzanego Tadeusza Maja, 26 V 1951 r., k. 319 i 327.

${ }^{143}$ Ibidem, Protokół przesłuchania podejrzanego Tadeusza Maja, 30 III 1953 r., k. 368. 
Ząbek [Edward Konopski] i Galant [Jan Kozieł] widzieli tych Żydów. Smotek, mający później pseudonim Klawisz, mówił mi, że „rozłupał” tych żydów - opowiadał, że ustawił ich rzędem i rozstrzelał ${ }^{144}$.

Z kolei oskarżony Kozieł zaraz po aresztowaniu opowiadał:

Po jakimś czasie od wypadku na Kotysce oddział nasz stacjonowal w lesie koło wsi Piotrowe Pole. Tu przyszła do nas grupa Żydów, około 5-7 ludzi, którzy prosili, aby ich przyjąć do oddziału. Byli to sami mężczyźni. Z prośbą tą zwracali się do dowództwa naszego oddziału. Dowództwo kazało im czekać do wieczora. Gdy nadszedł wieczór, oddział odmaszerował, Żydzi ci pozostali. Co z nimi się stało - nie wiem ${ }^{145}$.

\section{Lipie}

Trzeci przypadek, który szczegółowo zrelacjonował Jan Barszcz, dotyczy zdarzeń w leśniczówce Lipie koło Wierzbnika. Oddział „Świt” powracał wówczas z Wykusu w Górach Świętokrzyskich ${ }^{146}$. Żydów odkryto w stodole koło leśniczówki. Liczebność grupy niektórzy świadkowie szacowali od $3^{147}$ do 30 osób ${ }^{148}$. Podobno była między nimi jedna kobieta ${ }^{149}$. Barszcz opowiadał:

Poszliśmy [...] gremialnie zobaczyć i porozmawiać z nimi. Pytali się, co to za oddział, kto jest dowódcą i wszyscy wyrażali chęć wstappienia do naszego oddziału. Łokietek jednak nie zgodził się na przyjęcie tak dużo ludzi, było ich tam bowiem wszystkich razem około trzydziestu ludzi - kobiet nie widziałem. Co się z nimi stało, nie jest mi wiadomo. Mogę stwierdzić tylko tyle, że kiedy nasz oddział wyruszył w kierunku Klepacz, cała grupa żydów szła również za nami. Łokietek wyznaczył wtedy kilku ludzi, kogo, nie pamiętam, ażeby ich zatrzymać i nie pozwolić iść za oddziałem. Co się faktycznie $z$ tą grupą stało, nie jest mi wiadomo ani też nie słyszałem na ten temat żadnych komentarzy w oddziale.

Wersję Barszcza potwierdził inny żołnierz Maja, Jan Świtek:

W czasie, kiedy oddział nasz wracał z Wykusu [...] napotkaliśmy w leśniczówce Lipie grupę żydów, która ukrywała się tam w stodole - przypuszczalnie było ich około 15-20. Wyrażali oni chęć wstąpienia do oddziału, jednak

${ }^{144}$ APW, SW, IV3K.126/53, Protokół rozprawy głównej przeciwko Janowi Koziełowi, 13 III 1954 r., k. 60.

${ }^{145}$ APW, MBP, Protokół przesłuchania podejrzanego Jana Kozieła, 10 VI 1951 r., b.p.

146 Zob. na przykład Wieczorek, Armia Ludowa..., s. 101; zob. Tadeusz Orkan-Łęcki w: Wspomnienia żotnierzy GL i AL, s. 306.

${ }^{147}$ APW, SW, IV3K.126/53, Protokół rozprawy głównej przeciwko Janowi Koziełowi, 23 I 1954 r., Zeznanie Józefa Bugajskiego, k. 44.

${ }^{148}$ APW, MBP, Protokół przesłuchania świadka Jana Barszcza, 16 III 1951 r., b.p. Z kolei Jan Świtek określił liczebność grupy Żydów na 15-20 osób (ibidem, Protokół przesłuchania świadka Jana Świtka, Częstochowa, 21 III 1951 r., b.p.).

${ }^{149}$ Tracz na rozprawie głównej, zob. AAN, PG, 21/99, Sąd Wojewódzki m.st. Warszawy, Protokół rozprawy głównej, 27 III 1954 r., k. 515. 
nie zostali przyjęci. Kiedy oddział nasz ruszył w dalszą drogę i grupa żydów posuwała się za naszym oddziałem, zostali oni zatrzymani przez naszych ludzi, by nie szli za oddziałem. Bliższych szczegółów w sprawie tych ludzi nie jest mi wiadomo ${ }^{150}$.

Tadeusz Maj opowiedział o zdarzeniu w zbliżony sposób:

W niedługim czasie po tej akcji [nad Kotyska] w chwili kwaterowania mojego oddziału w okolicy miejscowości Lipie [...] doprowadzono do mnie kilku żydów na rozmowę. W rozmowie żydzi ci oświadczyli, aby ich przyjąć do oddziału. Przy rozmowie tej byli obecni Orkan-Łęcki, Dulka-Bakalarczyk i Wiślicz-Iwańczyk Edward [właśc. Eugeniusz]. Po tej rozmowie zdecydowaliśmy wspólnie nie przyjąć ich do oddziału. Mimo tej decyzji [...] po wyjściu mego oddziału z leśniczówki żydzi ci zwartą grupą szli za oddziałem. Na skutek tego poleciłem Orkanowi-Łęckiemu Tadeuszowi, aby został w tyle i cofnął idących za nami żydów. Orkan wówczas wraz z kilkoma żołnierzami został. Po krótkim czasie dołączył do oddziału i oświadczył, że odpędził już żydów. W jaki sposób on to zrobił, nie pytałem go, jak również i on mi o tym nie mówił ${ }^{151}$.

Dwa lata wcześniej na temat tego zdarzenia zeznawał członek oddziału „Świt”, Józef Bugajski ${ }^{152}$ :

wypadek miał miejsce po upływie około miesiąca czasu od poprzedniego [czyli od Kotyski], tj. przypuszczalnie w sierpniu 1944 w miejscowości Lipie pow. Starachowice. Oddział nasz w sile ok. 50 ludzi powracając z Gór Świętokrzyskich, nad ranem zakwaterował się w leśniczówce Lipie. Sam Łokietek z osobami najwięcej sobie zaufanymi jak Skóra, Dulka, Galant oraz zastępca Orkan znajdowali się wewnątrz leśniczówki, oddział natomiast rozłożył się w stodole. W tej też stodole znajdowało się czterech Żydów, którzy doprowadzeni zostali do Łokietka. Co z tymi osobami stało się, tego ja nie wiem, lecz więcej tych osób nie widziałem, i puszczone one nie zostały, gdyż był to dzień, co mogłoby zagrozić zdradzie [sic!] bezpieczeństwa oddziału, a Żydzi dla swojego bezpieczeństwa też nie mogliby się oddalić. Wystrzałów ja w tym czasie nie słyszałem, lecz należy przy tym nadmienić, że oddział nasz posiadał tłumniki strzałów „bezszumki” i tymi osoby wymienione mogły być stracone. W oddziale naszym był w tym czasie ps. Ząbek, który był wyróżniany przez Iwańczyka ps. Wiślicz, o którym opinia oddziału była taka, że Ząbek rozstrzeliwał Żydów. Opinia oddziału o powyższym była dosyć głośna i jemu nie szkodziła. [...] Uważam, że wyczyny Ząbka działy się za cichą zgodą Łokietka i Wiślicza. Stwierdzić mogę niezbicie, że Łokietek, a nawet i Orkan byli wrogo ustosunkowani do osób narodowości żydowskiej z ich wypowiedzi, które niejednokrotnie słyszałem, oraz z samego zachowania $\operatorname{sie}^{153}$.

\footnotetext{
${ }^{150}$ Ibidem, Protokół zeznania świadka Jana Świtka, 21 III 1951 r., k. 396.

${ }^{151}$ Ibidem, Protokół przesłuchania podejrzanego Tadeusza Maja, 27 V 1951 r., k. 327.

${ }^{152}$ Ibidem, Protokół przesłuchania świadka Józefa Bugajskiego, 22 IX 1949 r., k. 370.

${ }^{153}$ Ibidem, k. 372.
} 


\section{Mężczyźni i kobiety}

Na zwłoki dwóch mężczyzn koło leśniczówki Lipie (oddział nr 190) pod koniec lata 1944 r. natrafił leśniczy Giemza, którego zeznanie spisano w roku 1950. Znaleziono przy nich kartkę w języku „trochę ruskim” - „za współpracę z germańcem”. W swoim zeznaniu Giemza wspomniał też o innych zwłokach rozwłóczonych przez lisy nad Kotyską. Mogły to być ciała dwóch Żydów zastrzelonych na początku lipca nad Kotyską, wcześniej pochowane przez Bolesława Warszakowskiego i Jana Maja „Sęka”154. Jak się wydaje, to właśnie o pochowaniu tych ludzi mówił Jan Bugajski:

Jeden z zabitych nie miał jednego oka - według komentarzy, jakie były na ten temat prowadzone w oddziale Łokietka, był to niejaki Josek z Iłży, drugi młody, najwyźej 25 lat. [...] Gdyśmy ich ułożyli w dole, Maj Tadeusz - Łokietek, Bakalarczyk Adam ps. Dulka i Tracz Wacław ps. Skóra przeprowadzili rewizję w kieszeniach zabitych. Z kieszeni wyjęli pięć zegarków, pierścionki i pieniądze, które zabrali dla siebie. Ja zwróciłem się do Łokietka z prośbą, by mnie dał jeden zegarek, na to nic nie odpowiedział i zegarka nie dał. Następnie wszyscy nazbieraliśmy liści, którymi zabici zostali przykryci. Przy przykrywaniu trupów Łokietek Maj zwrócił się do wszystkich obecnych w te słowa: „O tym, coście tu widzieli, ani pary z ust nikomu, chociaż się wojna skończy, zrozumiano?"155

Leśniczy Giemza nadmienił jeszcze o znalezieniu ciał dwóch zamordowanych kobiet - jednej w oddziale nr 119 i drugiej w oddziale $n r 154^{156}$. Jedną z nich mogła być ofiara zabójstwa, którego świadkiem był inny żołnierz z oddziału Maja, Jan Świtek.

[Z]nany mi jest konkretny wypadek zamordowania żydów w lesie między Marculami a leśnictwem Lipie. Było to w końcu lipca 1944, jechaliśmy do Marcul po cukier dla oddziału, ja, ps. Orkan-Łęcki Tadeusz, ps. Galant - Kozieł Jan. W drodze spotkaliśmy w lesie żydówkę, lat około 28-32, ubrana była nędznie, miała na sobie już mocno podniszczoną chustkę, jaką noszą kobiety wiejskie w tamtej okolicy, wzrost średni, szczupła, szatynka. Żydówka ta z płaczem zatrzymała nas, prosząc o przyjęcie jej do oddziału. Kozieł Jan ps. Galant zszedł z wozu i powiedział: „ja cię zaprowadzę do oddziału”, wskazał jej kierunek, by szła w głąb lasu i on również poszedł za nią. Gdy weszli w zagajnik ok. 20 metrów od drogi, oddał krótką serię strzałów z automatu i wrócił z powrotem do wozu. Po przyjściu Galant powiedział do nas: „zaprowadziłem ją do oddziału”. Orkan zapytał Galanta ze śmiechem: „czy więcej nie będzie płakała?”, Galant odpowiedział: „na pewno nie”157.

${ }^{154}$ AAN, PG, 21/99, Protokół przesłuchania świadka Bolesława Warszakowskiego, Warszawa, 13 IV 1951 r., k. 411.

${ }^{155}$ Ibidem, Protokół przesłuchania świadka Józefa Bugajskiego, 22 IX 1949 r., k. 371.

${ }^{156}$ Ibidem, Protokół przesłuchania świadka Józefa Giemzy, 20 IV 1950 r., k. 377. Zob. także jego zeznanie w: APW, SW, IV3K.126/53, Protokół rozprawy głównej przeciwko Janowi Koziełowi, 23 I 1954 r., k. 45.

${ }^{157}$ AAN, PG, 21/99, Protokół zeznania świadka Jana Świtka, 21 III 1951 r., k. 395-396; ibidem, Notatka prokuratora Władysława Dymanta z 4 I 1954 r.: „Oskarżony Kozieł przyznał 
Inaczej zdarzenie to przedstawił na własnym procesie oskarżony Jan Kozieł „Galant”:

szedłem z Orkanem i innymi po aprowizację. Jakaś kobieta zaczepiła Orkana, a ten kazał mi zastrzelić ją, co też zrobiłem. [...] Jak ją zastrzeliłem, nie pamiętam. [...] Wypadek z Żydowką wywarł na mnie duże wrażenie. Mam jednak zbyt dużo przeżyć i dlatego nie przypominam sobie okoliczności jej śmierci. [...] Zastrzeliłem ją zdaje się z automatu. [...] Żydówka ta była w średnim wieku - nie była młoda i nie była stara ${ }^{158}$.

Więcej szczegółów zbieżnych z wcześniej cytowaną relacją Świtka oskarżony podał jednak w czasie śledztwa, 10 czerwca 1951 r. Zapamiętał na przykład, że kobieta „ubrana była w ubranie koloru czerwonego”159.

Prosiła ona Orkana-Łęckiego Tadeusza o przyjęcie do oddziału. Orkan zwrócił się do mnie, mówiąc: „Galant, zaprowadź ją do wiecznego oddziału”, co oznaczało, bym ją zastrzelił. Ja kazałem wtedy tej kobiecie iść do pobliskiego zagajnika. Zapytała mnie, czy pójdziemy do oddziału. Odpowiedziałem jej, że tak i wskazałem kierunek. W zagajniku oddałem do idącej przede mną kobiety serię strzałów z automatu, kładąc ją trupem na miejscu. Potem powróciłem do wozu i zameldowałem Orkanowi, że rozkaz wykonałem - pojechaliśmy dalej do Marcul ${ }^{160}$.

Wydając wyrok na Kozieła, sędzia K. Kaczyński postąpił identycznie jak przy wyrokowaniu w sprawie Tadeusza Maja. Identyczne jest nawet sformułowanie:

Sądowi nie udało się ustalić dokładnie, czy oskarżony działał z rozkazu Orkana, który był dowódcą tej grupy, czy też z własnej inicjatywy, przy aprobacie Orkana jako przełożonego ${ }^{161}$. [...] Wobec jednak powstałych wątpliwości sąd rozstrzygnął je w myśl zasady in dubio pro reo, na korzyść oskarżonego, przyjmując, że oskarżony działał na polecenie swego wojskowego dowódcy $^{162}$.

się jedynie do zabójstwa tej kobiety [w lesie koło wsi Marcule]”, k. 217. Czytamy tu również, że Kozieł został aresztowany 13 VI 1951 r. i jego sprawa będzie rozpatrywana przez Sąd Wojewódzki m.st. Warszawy 23 I 1954 r.

${ }^{158}$ W tym samym zeznaniu Jan Kozieł mówi: „Ja szedłem za nimi [tzn. za „Orkanem” i innymi], zdaje się z Ząbkiem i Giemzą”. Tymczasem leśniczy Giemza twierdzi, że w ogóle nie zna oskarżonego, zob. APW, SW, IV3K.126/53, Protokół rozprawy głównej przeciwko Janowi Koziełowi, 23 I 1954 r., k. 45.

${ }^{159}$ APW, MBP, Protokół przesłuchania podejrzanego Jana Kozieła, 10 VI 1951 r., b.p.

${ }^{160}$ APW, SW, IV3K.126/53, Przesłuchanie podejrzanego Jana Kozieła, 23 VI 1951 r., b.p.

${ }^{161}$ W teczce osobowej „Orkana” znajduje się jego Zeznanie własne, w którym opisał zastrzelenie tej kobiety przez Kozieła, pomijając własną rolę w zdarzeniu („nie pamiętam, co jej odpowiedziałem”), zob. AIPN, 00945/170, k. 44.

${ }^{162}$ APW, SW, IV3K.126/53, Wyrok w sprawie przeciwko Janowi Koziełowi, 16 III 1954 r., k. 71. Ani w tej, ani w żadnej innej sprawie Tadeusz Orkan-Łęcki nie został wezwany na świadka, nie wszczęto też przeciw niemu postępowania. 
Szczególnie drastyczna jest ostatnia sprawa, która wypłynęła w zeznaniach zastępcy Maja, Adama Bakalarczyka. We wrześniu lub październiku 1944 r. do oddziału przybyć miało troje ludzi, dwóch mężczyzn, o których mówiło się, że są Żydami, i kobieta o imieniu Basia.

Po kilku dniach - mówi Bakalarczyk - jeden z mężczyzn zniknął, w związku z tym oddział nasz zmienił miejsce postoju. W stosunku do pozostałych kobiety i mężczyzny przeprowadzono śledztwo. Konkretnie jakie wyniki dało śledztwo, nie wiem. Ww. kobieta i mężczyzna zostali rozstrzelani przez wyznaczonych przez Łokietka ludzi. Na temat tej likwidacji mówiono w oddziale, że przed egzekucją mężczyzna ów mówił, że jest żydem ${ }^{163}$.

Jan Kozieł dorzucił drastyczne szczegóły:

Pewnego razu staliśmy w okolicy Skarżyska w lesie. Podczas postoju słyszałem, że Orkan zastrzelił dwoje ludzi, którzy przebywali w naszym oddziale od kilkunastu dni. Była to niejaka ps. Basia i mężczyzna (pseudonimu nie znam). Jak opowiadano, Orkan bawił się z Basią, trzymając ją na kolanach. Gdy ta mocno się śmiała, ten z pistoletu strzelił jej w usta. Przedtem podobno Orkan żył z nią. Basia i tenże mężczyzna mieli być szpiegami niemieckimi, że doniosła o tym AK. Przy zabójstwie ich był prawdopodobnie i Łokietek ${ }^{164}$.

O tych wszystkich apektach przestępczej działalności Orkana jako zastępcy Tadeusza Maja czytamy też w zeznaniu Henryka Połowniaka:

Znany mi jest fakt z opowiadań, że ppłk Łęcki dyslokując swoim oddziałem w okolicach Małogoszcz-Kielce, przyjął do swojego oddziału dziewczynę imieniem Basia, rzekomo członek AK. Dziewczyna ta była o wyjątkowej urodzie, gdzie ppłk Orkan po paru dniach rozpoczął z nią bliższe współżycie, a po paru tygodniach wyszedł z nią na spacer do lasu i osobiście na jej osobie dokonał wyroku z broni krótkiej. Kiedy stawiano ww. zarzuty, ten

${ }^{163}$ AAN, PG, 21/99, Protokół przesłuchania świadka Adama Bakalarczyka, Warszawa, 16 II 1954 r., k. 457. Na rozprawie głównej Bugajski wspomniał jeszcze o jednym Żydzie, członku oddziału „Świt”, który miał pseudonim „Antek” (ibidem, Sąd Wojewódzki m.st. Warszawy, Protokół rozprawy głównej, 27 III 1954 r., k. 513). Natomiast sam Tadeusz Maj zeznał, że „w czasie postoju mojego oddziału w Dobieszowie lub okolicach zgłosiło się do oddziału małżeństwo. Mężczyzna, przydzielony do oddziału „Orkana”, miał zginąć w czasi szturmowania mostu, kobieta zaś miała przetrwać do wyzwolenia i po wojnie pracować w WUBP w Kielcach, potem zaś w Łodzi czy Tomaszowie” (ibidem, Protokół przesłuchania podejrzanego Tadeusza Maja, 5 VII 1951 r., k. 347).

${ }^{164}$ APW, MBP, Protokół przesłuchania podejrzanego, 10 VI 1954 r., b.p. Na temat krążących w środowiskach lewicowych plotek dotyczących „Żydów w Gestapo i SS”, formacji liczącej rzekomo 2000 Żydów z gett (zob. AAN, 191/XII-3, Meldunek o Żydach w Gestapo i SS, k. 308), piszą autorzy zbioru dokumentów Tajne oblicze GL-AL i PPR..., t. 2, s. 211: „Nie było specjalnej formacji SS, składającej się z 2000 Żydów. Rozpowszechnianie takich meldunków przez GL przyczyniało się do wzrostu nastrojów antysemickich w szeregach tej organizacji”. 
oświadczył, że ona była szpiegiem niemieckim. Tyle co mi wiadomo, to jego kochanka Basia nie była podejrzewana o współpracę z Niemcami ${ }^{165}$.

\section{Sprawa „Ząbka”}

Adiutantem „Wiślicza” był, jak wspomniano, plutonowy „Ząbek”"166. Jan Świtek zapamiętał jego obecność nad Kotyską w czasie pierwszego mordu. „Ząbek” był w grupie, która wraz z Majem udała się na miejsce egzekucji Żydów.

Gdy przyszedłem do obozu, spotkałem Ząbka przy kuchni, który wręczył mi buty [„oficerki z grubej skóry”], mówiąc: „masz, nie będziesz boso chodził”. Na moje pytanie, skąd on te buty wziął, odpowiedział: „zamknij gębę, a w butach chodź”. Buty, które mi Ząbek dał, rozpoznałem, że są to te same buty, w których uprzednio chodził ps. Szczęśliwy. W butach tych chodziłem do czasu, gdy zostałem ranny w mieście Włoszczowa przy niszczeniu torów kolejowych. Ząbek również miał na sobie nowe oficerki, których uprzednio przed wyprowadzeniem żydów w las nie miał, oraz nowe spodnie ${ }^{167}$.

O tym, że „Ząbek” „miał likwidować Żydów na własną rękę”, mówił wspomnianemu już Bugajskiemu Jan Maj „Sęk”168, natomiast Tadeusz Maj stwierdził, że „Ząbek odprowadzał Żydów do sztabu i miał ich likwidować"169. Warszakowski zeznał na procesie, że Ząbek „był szyderczy w stosunku do Żydów. Raz, gdy miał odprowadzić jednego Żyda do sztabu, to zastrzelił go po drodze" ${ }^{170}$. Jan Barszcz wspominał, że w październiku lub listopadzie 1944 r. między Majem i zastępcą dowódcy Orkanem-Łęckim doszło do kłótni, zakończonej odejściem z oddziału części ludzi, wśród nich także Barszcza. Zbuntowani udali się do domów. Po powrocie do Rzeczniowa Barszcz spotkał się z „Ząbkiem”, który z powodu przeziębienia i wrzodzianek od dłuższego czasu przebywał już we wsi, w domu Bugajskiego. „Ząbek” wyznał mu wtedy, że został na niego wydany wyrok śmierci. Domyślał się, że „rozkazodawcy, których polecenia wykonywał, o których jest mu dużo wiadomo, w obawie, by ich kiedykolwiek nie zdradził, wydali na niego wyrok"171. Domysły jego okazały się słuszne. Na początku listopada po Barszcza i „Ząbka” do wsi Rybiczyzna przyszedł Orkan-Łęcki w towarzystwie Kurka z Lipia i Marcelego Cukierskiego. Zabrali ich obu do lasu koło wioski.

${ }^{165}$ AIPN, 00945/170, Oświadczenie Henryka Połowniaka, k. 26.

${ }^{166}$ Wiślicz-Iwańczyk: „mój adiutant Ząbek” (Echa Puszczy Jodłowej, s. 272-273, 277, 281). Zob. też Wspomnienia żotnierzy GL i AL, wspomnienie Roga-Świostka, s. 339.

${ }^{167}$ AAN, PG, 21/99, Protokół zeznania świadka Jana Świtka, 21 III 1951 r., k. 393-394.

168 Określenie „na własną rękę” nie pada jednak w zeznaniu Bugajskiego na rozprawie przeciwko Janowi Koziełowi, zob. APW, SW, IV3K.126/53, Protokół rozprawy głównej przeciwko Janowi Koziełowi, 23 I 1954 r., k. 44v: „Słyszałem od Maja [Jan Maj „Sęk”], że Ząbek odprowadzał do Sztabu spotkanych po drodze Żydów i likwidował ich”.

${ }^{169}$ AAN, PG, 21/99, Sąd Wojewódzki m.st. Warszawy, Protokół rozprawy głównej, 27 III 1954 r., k. 513, 514.

${ }^{170}$ Zob. też ibidem, k. 519.

${ }^{171}$ Ibidem, Protokół przesłuchania świadka Jana Barszcza, 16 III 1951 r., k. 387-388. 
W lesie był oddział ps. Orkana ustawiony w dwuszereg. Po przyjściu do oddziału ja zacząłem rozmawiać z Bugajskim Józefem ps. Azja, który był w oddziale Orkana. W tym momencie usłyszałem serię wystrzałów tuż za sobą - obejrzałem się - na ziemi leżał zabity Ząbek - przez Orkana. Byłem przerażony tym wypadkiem, nie byłem pewien, czy i mnie ten sam los nie spotka, co przed chwilą Ząbka. Orkan zwrócił się do mnie, bym tu na miejscu, nie gdzie indziej, pochował ciało Ząbka i na miejscu czekał na dalsze rozkazy. Od tego czasu więcej Orkana nie widziałem. Nadmieniam, że Ząbek pracował w sztabie II Brygady AL „Świt” i bezpośrednio podlegał Wiśliczowi - był jego adiutantem ${ }^{172}$.

Świadkiem wykonania wyroku na „Ząbku” był też Bolesław Warszakowski, który zeznał:

Wykonanie wyroku odbyło się w lesie koło miejscowości Borsuki. Ząbek [...] został jesienią [...] rozstrzelany przed frontem oddziału. Orkan-Łęcki Tadeusz zwrócił się do Ząbka, że ma rozkaz go zastrzelić za to, że on, tj. Ząbek, sprzedaje broń i dopuszcza się rabunków. Następnie oddał do Ząbka serię strzałów z automatu, zabijając go na miejscu. Zagrzebać ciało Ząbka polecił Barszczowi ps. Grab z miejscowości Rybiczyzna. Zaznaczam, że w przeddzień wykonania wyroku na Ząbku przez Orkana w oddziale naszym był [Mieczysław] Świostek ps. Róg173 i Maj Tadeusz ${ }^{174}$ i dość długo rozmawiali z Orkanem ${ }^{175}$.

Zabójstwo Ząbka było prawdopodobnie związane ze zmianą polityki dowództwa, jaka - niezależnie od mordów już dokonanych, a także przyszłych - nastapiła w pierwszych dniach sierpnia 1944 r. Podczas gdy oddział przebywał na Wykusie w Górach Świętokrzyskich, Wiślicz-Iwańczyk przed frontem oddziału „piętnował rabowanie i używanie broni przeciwko niewinnym ludziom. Podkreślił przy tem, że kto się więcej dopuści takich rzeczy, będzie karany śmiercią"176.

172 Ibidem, k. 388. Barszcz dodał, że więcej na ten temat może powiedzieć „Przychodni” z oddziału „Łokietka”, pracujący w delegaturze Komisji Specjalnej. Po latach rozmawiali o tym w Kielcach i „Przychodni” miał wtedy powiedzieć, że „gdyby władze wiedziały o tych mordach, to by Wiślicz i Łokietek poszli do więzienia” (ibidem, k. 389). Relację o okolicznościach egzekucji na „Ząbku” potwierdził świadek na procesie Jana Kozieła, Józef Bugajski: „Ząbek po zdezerterowaniu został złapany i Orkan, mówiąc «za zdradę narodu», zabił go. Po pytaniu się Orkana, dlaczego to zrobił, ten powiedział, że jest taki rozkaz z okręgu” (APW, SW, IV3K.126/53, Protokół rozprawy głównej przeciwko Janowi Koziełowi, 23 I 1954 r., k. $44 \mathrm{v}-45$ ).

${ }^{173}$ Zob. np. Wieczorek, Armia Ludowa..., s. 203; Wspomnienia żotnierzy GL i AL, s. 294295, 338; Garas, Oddziaty Gwardii Ludowej i Armii Ludowej..., s. 232.

${ }^{174}$ AAN, PG, 21/99, Protokół przesłuchania świadka Bolesława Warszakowskiego, Warszawa, 13 IV 1951 r., k. 412.

${ }^{175}$ Ibidem, k. 412-413.

${ }^{176}$ AAN, PG, 21/99, Protokół przesłuchania świadka Jana Świtka, 21 III 1951 r., k. 396. 
„Wiślicz” i Sobczyński

Obecność „Wiślicza” w oddziale tego dnia, w którym nastąpiło rozstrzelanie Żydów nad rzeką Kotyską, oprócz Maja potwierdzili na rozprawie głównej Jan Barszcz (k. 383), Adam Bakalarczyk (k. 455) oraz Tracz, który zeznał:

Do oddziału przyjechał Wiślicz-Iwańczyk Eugeniusz [...] i przed frontem oddziału (wszyscy ustawieni byli w dwuszeregu) miał przemówienia. Co było tematem tego przemówienia, nie przypominam sobie. Pytano też, co komu brakuje z umundurowania, tzn. butów i z odzieży ${ }^{177}$.

„Świtowcy” zapamiętali też Władysława Sobczyńskiego. Oprócz Maja, który przypominał o nim najwytrwalej, o jego obecności wśród partyzantów krytycznego dnia zeznali Bakalarczyk ${ }^{178}$ i Kozieł ${ }^{179}$. Bakalarczyk wspominał ponadto, że Maj skarżył mu się, iż „Wiślicz i Sobczyński wydali mu rozkaz rozstrzelania całej grupy, a on zastrzelił tylko dwóch. Wyraził się, że niech takie sprawy załatwiają sobie sami" 180 .

Przez całe śledztwo Maj konsekwentnie powtarzał, że dwóch Żydów nad Kotyską zastrzelił na rozkaz przełożonych. W protokole końcowym w roku 1953 powołał się jeszcze na rozmowę z Orkanem, jaka odbyła się w obecności „Wiślicza”.

[W] roku 1946 na ten temat była luźna rozmowa podczas pobytu w Kielcach Łęckiego Tadeusza ps. Orkan, który spotkawszy mnie i Roga [-Świostka], zapytał mnie, co to ja miałem za sprawę likwidacji żydów podczas okupacji. Ja mu odpowiedziałem, że to jest sprawa Wiślicza, który stojąc obok nas, usłyszawszy te moje słowa, odwrócił się i nic nie powiedział181.

177 Ibidem, Protokół przesłuchania świadka Wacława Tracza, Warszawa, 27 III 1951 r., k. 401. Wersja o apelu z udziałem „Wiślicza” i Sobczyńskiego przed rozstrzelaniem Żydów nad Kotyską za: ibidem, Pismo Tadeusza Maja do Sądu Wojewódzkiego m. Warszawy, 1954 r., k. 476, oraz ibidem, Sąd Wojewódzki m.st. Warszawy, Protokół rozprawy głównej, 27 III 1954 r., Zeznanie Wacława Tracza, k. 515.

${ }^{178}$ Pismo adwokatów Aleksandra Soroki i Jana Załęskiego do Sądu Wojewódzkiego w Warszawie, 5 III 1954 r., w sprawie wezwania na rozprawę świadka Bakalarczyka. „W tym czasie, daty dokładnie nie pamiętam, przybył do oddziału Wiślicz [...] i Sobczyński [...] i konferowali z dowódcą oddziału [...] przez dwie-trzy godziny [...]. Bezpośrednio po ich odjeździe Maj Tadeusz [...] wydał rozkaz pójścia z nim” (ibidem, Protokół przesłuchania świadka Adama Bakalarczyka, Warszawa, 16 II 1954 r., k. 454).

${ }^{179}$ APW, MBP, Protokół przesłuchania podejrzanego Jana Kozieła, 10 VI 1951 r., b.p.: „Przed zarządzeniem zbiórki do naszego oddziału przyjechali Wiślicz i Sobczyński i coś konferowali z Łokietkiem i Orkanem-Łęckim”.

${ }^{180}$ AAN, PG, 21/99, Protokół przesłuchania świadka Adama Bakalarczyka, Warszawa, 16 II 1954 r., k. 457.

${ }^{181}$ Ibidem, Protokół końcowego przesłuchania podejrzanego Tadeusza Maja, Warszawa, 20 V 1953 r., k. 419. 
W trakcie ostatniego przesłuchania w 1953 r. Maj wnosił o przesłuchanie Sobczyńskiego i Wiślicza-Iwańczyka ${ }^{182}$. Jak wspomniałam, prośbę jego uwzględniono 18 września 1953 r., najpierw wzywając na świadka Sobczyńskiego. Oświadczył on, że „zasadniczo nie należał do żadnej grupy partyzanckiej, ale tylko się z nimi poruszał, wykonywując swoje zadania specjalne [wywiadowcze], otrzymane na terenie Związku Radzieckiego"183. Dopiero w lipcu 1944 r., po stracie radzisty, który przekazywał jego informacje Rosjanom, miał przyjać „propozycję wstąpienia do Sztabu III obwodu AL, na czele którego stał Moczar”. Został mianowany „szefem bezpieczeństwa”. Obwodowi temu podlegała między innymi grupa „Świt”, którą dowodził Wiślicz-Iwańczyk. Grupa dzieliła się na oddziały, wśród których był też oddział Maja ${ }^{184}$. W odróżnieniu od „Wiślicza”185 Sobczyński stwierdził też, że nigdy nie widział w pobliżu oddziału żadnej grupy Żydów.

Sobczyński wspominał, że po wojnie rozmawiał z Bugajskim na temat rozstrzelania „13 Żydów”186, a dokumentację tej rozmowy przesłał swoim przełożonym w MBP. W roku 1951 był na tę okoliczność przesłuchiwany w tym ministerstwie ${ }^{187}$. Napomknął też, że w roku 1952 w jakimś PGR rozmawiał z „Wiśliczem” o Maju i dokonanym przez niego zabójstwie. „Zauważyłem, że Wiślicz bardzo niechętnie na ten temat mówił”"188. Dopiero w roku 1958 w trakcie rewizji nadzwyczajnej wyroku sprzed pięciu lat prokurator generalny wprost zapytał Sobczyńskiego, czy wydał Majowi rozkaz przeprowadzenia egzekucji. Przesłuchiwany zaprzeczył, dodając jednak, że znane są mu przypadki likwidowania „ludzi, którzy kręcili się koło oddziałów partyzanckich i zdradzali położenie tych oddziałów”189. Nie wykluczył, że będąc w grupie „świtowców”, wyraził pogląd, iż takich ludzi należy

${ }^{182}$ Ibidem, Protokół końcowego przesłuchania podejrzanego Tadeusza Maja, Warszawa, 21 V 1953 r., k. 421.

${ }^{183}$ Ibidem, Protokół przesłuchania świadka Władysława Sobczyńskiego, Warszawa, 18 IX 1953 r., k. 429.

${ }^{184}$ Ibidem. Sobczyński wspomina tu o tym, że Maj nie wykonał rozkazu, by rozstrzelać partyzanta w Brodach, i nie zabrał mu broni, a także wypuścił „dwóch akowców, podejrzanych o współpracę z Niemcami i dokonujących zabójstw na sympatykach PPR”. Twierdzi, że Maj uniemożliwił też likwidację „innego współpracownika Niemców”, Flisa „Robura”, dowódcy oddziału AK na tym terenie, który potem przeszedł do AL.

${ }^{185}$ Wiślicz-Iwańczyk stwierdził na procesie, że kiedy był w oddziale Łokietka, widział raz „grupę Żydów kręcącą się koło oddziału”, k. 525.

${ }^{186}$ AAN, PG, 21/99, Protokół przesłuchania świadka Władysława Sobczyńskiego, Warszawa, 18 IX 1953 r., k. 431.

${ }^{187}$ Wskutek zarzutu Biura Specjalnego o współuczestnictwo w mordowaniu Żydów podczas walk partyzanckich w AL w roku 1952 odwołano go ze stanowiska w organach bezpieczeństwa. O ekscesach antysemickich Sobczyńskiego jako dyrektora Biura Paszportów zob. AIPN 703/1132, Meldunek Henryka Piaseckiego, wicedyrektora Biura Specjalnego MBP, do ministra Stanisława Radkiewicza, 4 VII 1951 r., k. 166-169.

${ }^{188}$ AAN, PG, 21/99, Protokół przesłuchania świadka Władysława Sobczyńskiego, Warszawa, 18 IX 1953 r., k. 431.

${ }^{189}$ Ibidem, Protokół przesłuchania świadka Władysława Sobczyńskiego, 12 XI 1958 r., k. 644 . 
likwidować. Domniemywał zarazem, że „Maj mógł zastrzelić tych Żydów na polecenie Wiślicza"190.

Miesiąc później na przesłuchanie został wezwany Wiślicz-Iwańczyk. Potwierdził opinię o Maju jako żołnierzu niesubordynowanym, wspomniał o jego dezercji jesienią 1944 r. i nadmienił, że odmówił on likwidacji Antoniego Hedy-Szarego, „który czynnie zwalczał oddziały PPR przez dokonywanie zabójstw”191, a także dwóch innych akowców. Stwierdził, że o dokonaniu przez oddział Maja zabójstwa nad Kotyską nie miał pojęcia, dopóki 2-3 tygodnie od zdarzenia nie dowiedział się o tym od Sobczyńskiego. Informować miał on swojego kolegę Jana Foremniaka ${ }^{192}$, że Żydzi ci tułali się koło oddziału i „szpiegowali ten oddział”193. Pamiętał, że „Foremniak na to odpowiedział słowem «spekulanci», mając na myśli tych żydów”194. Po pewnym czasie miał powiedzieć Sobczyńskiemu, że „postępowanie Łokietka również mu się nie podoba, na co Sobczyński nic nie odpowiedział”.

Na koniec zapewnił kategorycznie, że ,jest zupełną nieprawdą, jakoby wydał Łokietkowi rozkaz zastrzelenia Żydów”, i nie zna „żadnego Kamińskiego z Iłży” ${ }^{195}$. Na procesie stwierdził: „Najprawdopodobniej w dniu zabójstwa nie byłem w oddziale Łokietka”196. Tylko raz niezspodziewanie dodał: „Raz we trzech, tzn. ja,

${ }^{190}$ Ibidem, Protokół przesłuchania świadka Władysława Sobczyńskiego, Warszawa 18 IX 1953 r., k. 431

${ }^{191}$ Ibidem, Protokół przesłuchania świadka Eugeniusza Wiślicza-Iwańczyka, 16 X 1953 r., k. 432-435. Por. wypowiedź o ponad dziesięć lat późniejsza: „nie możemy powiedzieć o jakiejś ostrej walce oddziałów Szarego z naszymi” (AAN, 8500, Akta osobowe Eugeniusza Wiślicza-Iwańczyka, „Działalność organizacji «Świt» i II Brygady AL Ziemi Kieleckiej na Kieleczczyźnie w latach 1942-1945”, maszynopis, 1968 r.). Por. bałamutne opowieści o Antonim Hedzie „Szarym” opublikowane przez Wiślicza-Iwańczyka w Echach Puszczy Jodłowej, s. 64-68. O kontaktach Maja z „Szarym” zob. też zeznania Maja (AAN, PG, 21/99, k. 346).

${ }^{192}$ Jan Foremniak, przedwojenny komunista z Ostrowca Świętokrzyskiego, radziecki spadochroniarz. Mianowany pierwszym wojewodą kieleckim, zastrzelony przez żołnierza AK w 1944 r. Pierwowzór postaci komunisty Szczuki w Popiele i diamencie Jerzego Andrzejewskiego. Informacji podanej przez Wiślicza-Iwańczyka (AAN, PG, 21/99, Protokół przesłuchania świadka Eugeniusza Wiślicza-Iwańczyka, 16 X 1953 r., k. 432-435) Sobczyński zaprzeczył w zeznaniu przed prokuratorem generalnym w trakcie rewizji nadzwyczajnej wyroku zasądzonego Majowi (ibidem, Protokół przesłuchania świadka Władysława Sobczyńskiego, 12 XI 1958 r., k. 644).

${ }^{193}$ Wiślicz-Iwańczyk powtórzył to na procesie, zob. ibidem, Protokół rozprawy głównej przeciwko Majowi Tadeuszowi, 27 III 1954 r., k. 525.

${ }^{194}$ Ibidem, Protokół przesłuchania świadka Eugeniusza Wiślicza-Iwańczyka, 16 X 1953 r., k. 434.

${ }^{195}$ Ibidem, k. 435.

${ }^{196}$ AAN, PG, 21/99, Protokół rozprawy głównej przeciwko Tadeuszowi Majowi, 27 III 1954 r., k. 525. W piśmie do Rady Państwa z 25 VI 1954 r. brat Tadeusza Maja Franciszek donosił: „dopiero na korytarzu w dniu rozprawy, już po zeznaniach [Wiślicz-Iwańczyk] przyznal się, że był w tym dniu w oddziale” (ibidem, Pismo Franciszka Maja do rady Państwa, 25 VI 1954 r., k. 552). 
Sobczyński, Foremniak, poszliśmy do oddziału Łokietka, on mówił nam, że zabrał Żydom pieniądze, a z tymi, którzy nie chcieli oddać, rozprawił się"197.

\section{Jak oskarżony Maj sam rozumie swoje zachowanie}

W pierwszych przesłuchaniach Maj tłumaczył swoje zachowanie „burżuazyjnymi wpływami”, którym uległ, a także podżeganiem do zbrodni przez przełożonych:

Mordując żydów nad rzeką Kotyską, kierowałem się przede wszystkim rozkazem [...], a ponadto pozostały u mnie jeszcze sprzed wojny uprzedzenia do żydów jako do spekulantów ${ }^{198}$, wyzyskiwaczy, spowodowane uprawianą przez sanację propagandą. Jako też mój stosunek do żydów był pogardliwy i uważałem, że dla takich nie może być miejsca w nowej Polsce ${ }^{199}$.

Będąc pod wpływem wychowania burżuazyjnego, traktowałem Żydów jako wrogów nowego porządku i nie chciałem, aby doszli oni do władzy w Polsce $^{200}$.

Zabójstwo tych żydów wykonania polecenia [sic!] Sobczyńskiego bez żadnego oporu było pewnym następstwem wpływów antysemickich i nacjonalistycznego wychowania i otoczenia, w którym znalazłem się w okresie wojny $^{201}$.

Na rozprawie głównej w marcu 1954 r. Maj, od pewnego czasu świadom bezskuteczności delegowania odpowiedzialności na przełożonych, sięgnął po oskarżenia pod adresem zabitych Żydów. Stwierdził, iż rzeczywiście słyszał, „że zorganizowana jest przez Niemców grupa dywersyjna, w której są także Żydzi” i że „nie ma pewności, że ci Żydzi uciekli z obozu”202. Wersję tę potwierdził teź świadek Tracz, o którym wszyscy zeznawali, że uczestniczył w egzekucji. „Krążyły wersje, że za-

${ }^{197}$ Ibidem, Protokół rozprawy głównej przeciwko Tadeuszowi Majowi, 27 III 1954 r., k. 525 .

${ }^{198}$ Por. w zeznaniu Wiślicza-Iwańczyka sformułowany przez Foremniaka epitet „spekulanci” o kręcących się wokół oddziału Żydach. Zob. też pismo żony Maja Eugenii do Franciszka Jóźwiaka, przewodniczącego Komisji Kontroli Partyjnej z 21 II 1953 r.: ,jeden z tych żydów zabitych był posiadaczem kilku wapienniaków w Błazinach, poza tym handlarzem zboża i innych artykułów, był najbogatszym kapitalistom [sic!] w Iłży. Brat jego w czasie okupacji był policjantem żydowskim, jeździł z żandarmami po okolicznych wioskach odbierać rzeczy żydowskie” (AAN, PG, 21/99, k. 90). Zob. Joanna Tokarska-Bakir, Figura krwiopijcy $w$ dyskursie religijnym, narodowym i lewicowym Polski roku 1945/1946. Studium z antropologii historycznej, „Sprawy Narodowościowe. Seria Druga” 2010, nr 27, s. 19-48.

${ }^{199}$ AAN, PG, 21/99, Protokół przesłuchania podejrzanego Tadeusza Maja, 27 V 1951 r., k. 325.

${ }^{200}$ Ibidem, Protokół przesłuchania podejrzanego Tadeusza Maja, 26 V 1951 r., k. 322.

${ }^{201}$ Ibidem, Protokół końcowego przesłuchania podejrzanego Tadeusza Maja, Warszawa, 20 V 1953 r., k. 418.

${ }^{202}$ Ibidem, Sąd Wojewódzki m.st. Warszawy, Protokół rozprawy głównej, 27 III 1954 r., k. 505. 
strzelony był szpiegiem niemieckim”203 - powiedział. - „Słyszałem, jak chłopcy mówili, że jeden z zabitych jest agentem Gestapo”204. Identycznie zachowywał się kolejny uczestnik rozstrzelania, Bakalarczyk. Zapewniał, że ów „Kamiński”, którego rozstrzelali, był charakterystycznym „mężczyzną bez nosa”205 - łatwo go było rozpoznać.

Wkrótce na rozprawie pojawił się świadek Stefan Winiarski z Iłży, który zeznał, że w czasie okupacji mieszkał w Iłży naprzeciwko komisariatu i widywał owego Kamińskiego, gdy odwiedzał on posterunek żandarmerii. Miał być on policjantem żydowskim, „ludzie mówili, że został zabity, gdyż miał wydawać ludzi Niemcom. Zabity został w 1944 na wiosnę, kiedy utworzono getto [sic!]”206. Ze względu na oczywiste wątpliwości odnośnie do daty śmierci owego Kamińskiego słowa Winiarskiego nie odnosły oczekiwanego skutku. Sprawę uratował kolejny świadek, Szepietowski z Iłży, który poinformowany przez łączniczkę o ciele znalezionym w lesie miał wysłać na miejsce jakiegoś „,sekretarza PPR”, ten zaś ustalił, że jednym z zabitych jest „Kamiński [...] [którego] brat był burmistrzem; mówiono, że zabójstwo było odgórnie załatwione"207. Z sentencji wyroku wynika, że sąd ostatecznie odrzucił tezę, jakoby Żydzi byli konfidentami gestapo ${ }^{208}$.

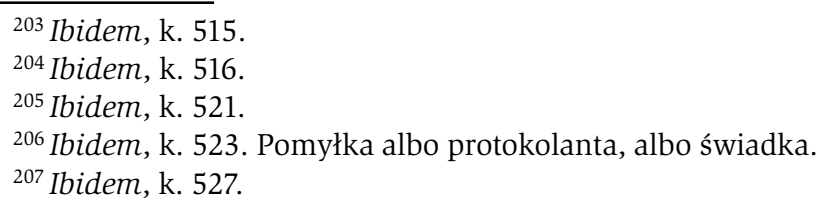

${ }^{208}$ Ta wersja powróciła w rewizji nadzwyczajnej, którą wniosła Prokuratura Generalna w roku 1958, zob. AAN, PG, 21/99, Wyrok Sądu Najwyższego PRL, 16 VI 1958 r., k. 574n. Sąd Najwyższy uchylił wyrok z 30 III 1954 r. i skierował sprawę do ponownego rozpoznania. Na posiedzeniu niejawnym Sąd Wojewódzki m.st. Warszawy w dniu 19 VII 1958 r. odesłał sprawę Maja do uzupełnienia „w kierunku ustalenia, czy jeden z zabitych (pierwszy) istotnie był agentem Gestapo” (k. 581). Jak wynika z odręcznej notatki z 13 IX 1958 r., ewentualność współpracy Kamińskiego z Iłży z Niemcami prokurator Tadeusz Miernik usiłował wyjaśnić, rozmawiając z ówczesnym dyrektorem ŻIH Adamem Rutkowskim (k. 594). Z notatki z 7 X 1958 r. dowiadujemy się, że „ob[ywatel] A. Rutkowski nie potrafi wskazać na takie materiały”, aczkolwiek „nie wyklucza, ażeby w tym czasie (lipiec 1944) jakiś Żyd nie mógł współpracować z Niemcami” (k. 604). 14 X 1958 r. Miernik wezwał na przesłuchanie Stefana Winiarskiego z Iłży (k. 606) i usłyszał od niego opowieść o Kamińskim („o zeszpeconym nosie”), którego stryjeczny brat, żydowski milicjant, miał być synem Borucha, starszego gminy żydowskiej w Iłży. Ów Kamiński „chodził razem z tym milicjantem”, odwiedzając posterunek żandarmerii. Również 14 października Miernik przesłuchał innego mieszkańca Iłży, Mariana Mąciwodę (w roku 1956 karanego z art. 39 kk), który potwierdził wersję o stryjecznym bracie Kamińskiego („bez nosa”), będącym milicjantem żydowskim (k. 609) - bracia „razem chodzili”. Świadek zeznał, że zetknął się z grupą około 12 Żydów zbiegłych z obozu w Starachowicach. Mieli oni zostać wymordowani przez Niemców (żandarmi spalili wtedy gajówkę Bukowiny), z wyjątkiem niejakiego Langera, który wyjechał za granicę (k. 610). (Być może przypadkowa zbieżność nazwisk: w częściowo opublikowanych wspomnieniach Wiślicza-Iwańczyka pojawia się „zamieszkała u nas, uratowana przeze mnie i przez moją żonę Estera Langerowa z Iłży (obecnie zamieszkała w USA)”, zob. Antyżydowskie wydarzenia kieleckie 
Kiedy hipoteza o Żydach - niemieckich szpiegach upadła, Maj ponownie usiłował podjąć samokrytykę. Podkreślił w niej, że czyn nie pasuje do jego charakteru.

Ja nigdy nie byłem antysemitą, nigdy ani w czynie, ani w słowie nie ujawniałem wystąpień antysemickich. Na decyzję rozstrzelania miała wpływ fałszywa ocena polegająca na biernym stosunku do Żydów, która wyrobiła u mnie pogląd, że żydzi są narodem o niższym charakterze. Twierdzę, że do wypadku nigdy by nie doszło, gdyby nie było podżegania ze strony Wiślicza i Sobczyńskiego ${ }^{209}$.

Na dowód prawdziwości swoich słów przypomniał sądowi, że w jego oddziale było kilku Żydów ${ }^{210}$. Istotnie, od sierpnia 1944 r. w II Brygadzie AL „Świt” znajdowało się sześć osób narodowości żydowskiej: lekarz „Adam” z żoną „Ireną"111, wspomniana już wcześniej Basia i dwaj nieznani z imion mężczyźni, „kucharz i fryzjer”212.

4 lipca 1946 roku. Dokumenty i materiaty, t. 2, oprac. Stanisław Meducki, Kielce: Kieleckie Towarzystwo Naukowe, 1994, s. 85; zob. też Wiślicz-Iwańczyk, Echa Puszczy Jodłowej, s. 213 (o leśniczym Langerze). Przesłuchiwano następnie między innymi także Tracza, który jeszcze raz potwierdził rozkaz wydany Majowi przez Sobczyńskiego i „Wiślicza” i przypomniał sobie, że jeden z rozstrzelanych nosił nazwisko Kamiński (AAN, PG, 21/99, Wyrok Sądu Najwyższego PRL, 16 VI 1958 r., k. 622), oraz Stanisława Paździurę z Iłży, który poświadczył współpracę Kamińskiego o „zeszpeconym nosie” z żandarmerią (k. 657). Śledztwo w sprawie Maja umorzono (AAN, PG, 21/99, Postanowienie o umorzeniu śledztwa, 21 XI 1958 r., k. 658), uznano bowiem, że „zabici współpracowali z Niemcami”, w związku z czym zaniechano wyciągnięcia konsekwencji wobec Maja. Por. także list brata Maja Wacława do prezydenta Bolesława Bieruta, w którym współpracujący z Niemcami Kamiński określony został jako „brat stryjeczny jednego z tych zabitych”, a zatem ktoś, kogo w obozie partyzantów nigdy nie było (ibidem, List Wacława Maja do prezydenta Bolesława Bieruta, k. 62).

${ }^{209}$ AAN, PG, 21/99, Sąd Wojewódzki m.st. Warszawy, Protokół rozprawy głównej, 27 III 1954 r., k. 504.

${ }^{210}$ Ibidem, Protokół przesłuchania podejrzanego Tadeusza Maja, 26 V 1951 r., k. 317.

${ }^{211} \mathrm{Na}$ ich temat zob. ibidem, Protokół przesłuchania świadka Józefa Bugajskiego, 22 IX 1949 r., k. 373. W zeznaniu mjr. Henryka Połowniaka: „Znany mi fakt, gdzie w jego [tzn. „Orkana”] oddziale było małżeństwo narodowości żydowskiej, doktor chirurg, docent, którego ppłk Łęcki prześladował za pochodzenie narodowościowe, naigrawał się zawsze i na każdym kroku nie dawał spokoju. Na potwierdzenie tego faktu powołuję się na świadka, kiedyś mi podległego szefa Sztabu I Brygady AL Ziemi Kieleckiej, obecnie ppłk. Adama Korneckiego, pracownika Sztabu Generalnego Oddział II” (AIPN, 00945/170, Oświadczenie Henryka Połowniaka, k. 26). Tadeusz Maj wymienił jeszcze trzy inne osoby, o których losie nic nie powiedział. Nie jest wykluczone, że byli to ludzie, o których wspominałam w sekcji „Kobiety i mężczyźni”.

${ }^{212}$ APW, MBP, Protokół przesłuchania podejrzanego Jana Kozieła, 10 VI 1951 r., b.p. Kozieł powiedział o nich więcej w zeznaniu z 23 VI 1951 r.: „przypominam sobie, że po utworzeniu II Brygady «Świt» było w naszym oddziale dwóch Żydów, jeden fryzjer, jeden kucharz. [...] W końcu sierpnia lub z początkiem września 1944 obydwaj zostali użyci do bardzo trudnej akcji wysadzenia w powietrze mostu kolejowego. Most ten był dobrze strzeżony przez Niemców siedących w bunkrach. W akcji tej obydwaj zginęli - mostu nie wysadzono" (AIPN, 00945/170, Protokół przesłuchania podejrzanego Jana Kozieła, k. 30). 
Wzmianki o nich powróciły także w zeznaniu Bakalarczyka ${ }^{213}$. Szóstą osobą był przydzielony przez sztab Bronisław Jaworski ${ }^{214}$. Tylko ten ostatni przeżył swój pobyt w oddziale AL „Swit”.

Płk Jaworski „Michał”, jesienią 1944 r. zbrojmistrz i doradca ds. uzbrojenia w oddziale Maja-Łokietka, po wojnie pracownik MON, zeznawał na jego procesie.

AL przydzieliło mnie do Brygady „Świt” [...]. Oskarżony nie wiedział z początku, że jestem narodowości żydowskiej, dowiedział się później. Oskarżonego stosunek do mnie uległ zmianie po pewnym czasie, z początku byłem jego prawą ręką, całym doradca, a potem zostałem usunięty na drugi plan. Do oddziału przyszedłem na początku sierpnia, [...] w tym okresie dochodziły do mnie wiadomości, że jakoby miały miejsce rabunki Żydów, którzy uciekali ze Starachowic z obozu, ale kto ich dokonywał, nie wiem. [...] Ja byłem w Brygadzie od sierpnia do października, dłuższy mój pobyt w Brygadzie okazał się niepotrzebny, bo zostałem „zdekonspirowany” [jako Żyd], więc zwróciłem się do Moczara, który kazał mi wracać do dowództwa. Do Brygady przydzielony byłem jako doradca dowódcy oddziału. To, że jestem Żydem, poderwałoby autorytet oficera Armii Ludowej i po „zdekonspirowaniu" mnie nie mogłem już wykonywać moich zadań ${ }^{215}$.

Wyrok w procesie dowódcy oddziału „Świt” zapadł 30 marca 1954 r. Tadeusza Maja skazano na osiem lat więzienia i utratę praw publicznych na trzy lata ${ }^{216}$. W sentencji czytamy, że „naród polski [...] z wyjątkiem nielicznej garstki zdrajców i renegatów spod znaku NSZ i AK nie dał się wciągnąć na [...] faszystowsko-nazistowską drogę i walczył pod przewodem rewolucyjnych organizacji o wolność dla wszystkich obywateli polskich bez względu na wyznanie, narodowość, płeć czy wiarę"217.

${ }^{213}$ O fryzjerze i buchalterze w oddziale zob. AAN, PG, 21/99, Sąd Wojewódzki m.st. Warszawy, Protokół rozprawy głównej, 27 III 1954 r., k. 522. Na temat dwóch Żydów zatrudnionych w jakimś lewicowym oddziale w charakterze fryzjera i buchaltera zob. świadectwo Gershona Rosenwalda: „After a while we met another group of Polish partisans who took the rest of our Polish money. I recognized one of them and told him that they took our money, and the commander went, gave us back the money and took in three of us - an accountant, a barber and one other" (http://www.jewishgen.org/yizkor/Wierzbnik/Wierzbnik.html\#Page381, dostęp 6 IX 2011 r.).

${ }^{214}$ Zob. Wiślicz-Iwańczyk, Echa Puszczy Jodłowej, s. 259-260, kpt. Bronisław Jaworski („Michał”), miner i zbrojmistrz, prowadził szkolenie w zakresie broni.

${ }^{215}$ AAN, PG, 21/99, Sąd Wojewódzki m.st. Warszawy, Protokół rozprawy głównej, 27 III 1954 r., Zeznanie płk. Bronisława Jaworskiego „Michała”, k. 520.

${ }^{216}$ Ibidem, Sentencja wyroku Sądu Wojewódzkiego dla m.st. Warszawy, 30 III 1954 r., k. 534. Półtora roku później, 25 X 1955 r., Tadeusz Maj został przedterminowo zwolniony z więzienia, zob. ibidem, Pismo prokuratora m.st.Warszawy do Sądu Wojewódzkiego dla m.st. Warszawy, 4 XI 1955 r., k. 563. Była to przerwa w odbywaniu kary. Wniosek o zgodę podpisała wicedyrektor Departamentu III MBP Alicja Graff, 21 IX 1955 r. (ibidem, k. 273). Maj do więzienia już nie powrócił.

${ }^{217}$ AAN, PG, 21/99, Sentencja wyroku Sądu Wojewódzkiego dla m.st. Warszawy, 30 III 1954 r., k. 537. 


\title{
Konkluzja
}

Wydźwięk materiałów archiwalnych dotyczących mordów na Żydach dokonanych przez członków oddziału „Świt”, a następnie II Kieleckiej Brygady AL o tej samej nazwie, można sprowadzić do słów, które wypowiedział jeden z morderców, Jan Kozieł: „biorąc pod uwagę dokonywane likwidacje i samo ustosunkowanie się dowództwa do tych wypadków”, można uznać, że stosunek oddziału „Świt” „do ludności narodowości żydowskiej był wrogi”218.

Zrekonstruowana w niniejszym artykule historia procesu Tadeusza Maja i innych nigdy niezakończonych procesami dochodzeń w sprawie mordów na Żydach, dokumentuje napięcia, jakie na przełomie lat czterdziestych i pięćdziesiątych rozdzierały komunistyczny aparat władzy, niechętny dochodzeniu prawdy o Zagładzie. Na badanie jej decydowano się wówczas, gdy dotyczyła przeciwników politycznych, a w związku z tym, że w okresie bezpośrednio poprzedzającym śmierć Stalina konfiguracja sił ciągle się zmieniała, śledztwa w takich sprawach prowadzone były opieszale i niekonsekwentnie. Wyjątkiem od tej reguły wydają się działania nadzorowane przez Józefa Światłę, wicedyrektora Biura Specjalnego X Departamentu MBP, między innymi w sprawie o kryptonimie „Jesion”, dotyczącej Eugeniusza Wiślicza i grupy partyzantów „Świtu”. Nie jest wykluczone, że wiedza o zakresie wojennego i powojennego antysemityzmu lewicy uzyskana przez niego w trakcie tego śledztwa stała się jedną z przesłanek stojących za jego decyzją o ucieczce na Zachód.

\section{Słowa kluczowe}

Tadeusz Maj, oddział AL „Świt”, Kielecczyzna, mordy na Żydach, procesy powojenne

\begin{abstract}
Tadeusz Maj - one of the major commanding officers of the partisan units of the People's Army (Armia Ludowa, AL) in Poland during World War II - was arrested in 1951. He was charged with murders on Jews in the forests near Iłża committed in the period from June/July 1944 to December that year. The victims of the People's Army "Świt” detachment under Maj's command were Jewish escapees from the labor camp in Starachowice, who decided to escape to the forest after they had found out that they would be deported to Birkenau at the end of June 1944. The article reconstructs the history of Tadeusz Maj's trial and of other investigations on the murders on the Jews, which were never brought to an end. It documents the tensions at the turn of the 1940s and 1950s visible within the communist party apparatus, which was reluctant to investigate the truth about the Holocaust.
\end{abstract}

\section{Key words}

Tadeusz Maj, People’s Army “Świt” detachment, Kielce region, murders on Jews, post-war trials

${ }^{218}$ AIPN, 00945/170, Protokół przesłuchania podejrzanego Jana Kozieła, k. 32. 